\title{
Intervention Retrofitting and Rehabilitation of Al-Gawhara Palace at the Saladin Citadel, Cairo, Egypt
}

\author{
Sayed Hemeda ${ }^{\mathbb{B}}$, Taha Abd El Moaty Atalaa \\ Conservation Department, Faculty of Archaeology, Cairo University, Cairo, Egypt \\ Email: sayed.hemeda@cu.edu.eg
}

How to cite this paper: Hemeda, S. and El Moaty Atalaa, T.A. (2019) Intervention Retrofitting and Rehabilitation of Al-Gawhara Palace at the Saladin Citadel, Cairo, Egypt. Open Journal of Geology, 9, 109-141. https://doi.org/10.4236/ojg.2019.93009

Received: February 12, 2019

Accepted: March 2, 2019

Published: March 5, 2019

Copyright $\odot 2019$ by author(s) and Scientific Research Publishing Inc. This work is licensed under the Creative Commons Attribution International License (CC BY 4.0).

http://creativecommons.org/licenses/by/4.0/

\section{Abstract}

Al-Gawhara Palace also known as Bijou Palace is located in the south of the Mosque of Muhammad Ali in Saladin Citadel in Cairo (Figure 1 and Figure 2). It was commissioned and constructed by Muhammad Ali Pasha in 1814. Al-Gawhara Palace is one of the most famous historical royal palaces in Egypt and the most important modern architectural heritage that reflects an important historical period of the Egyptian modern history-the period of the rule of the family of "Muhammad Ali Pasha". The causes of structural deficiency of the palace could be attributed to many reasons and actions, mainly due to the earthquakes and seismic events (in particular the Dahshuor earthquake, in October 1992), degradation of drainage and feeding systems leading to water leakage, lack of awareness of the palace values, deterioration resulting from the use of old government agencies and the conflicts among authorities supervising historical buildings. The present study includes many phases: 1) the significance of the original building from the circumstances and date of construction; 2) detailed studies of the architectural features and design of the building as well as construction type, methods and techniques of construction; 3) characterization of the construction and building materials; 4) stability analysis of the structure under static and the impact of seismic loadings; 5) engineering measures for intervention retrofitting of the palace (this pilot study presents the main design studies for intervention retrofitting and the rehabilitation and re-employment of Al-Gawhara Palace, started from the static monitoring, old and modern documenting of the current state of preservation thorough the strengthening project implementation; 6) the study also presents the reuse designs to convert the palace to be a national museum, for the purpose of preserving it by proposing the best means to apply the cor- 
rect principles and criteria for reuse and employment in a manner that preserves its value through the functions that fit these deficiencies, and the appropriateness of the present function of the value of minors.

\section{Keywords}

Al-Gawhara Palace, Structural Deficiency, Restoration, Intervention

Retrofitting, Rehabilitation, Structural Analysis, Reuse

\section{Introduction}

Al-Gawhara Palace was designed and constructed by artisans contracted from a variety of countries, including Greeks, Turks, Bulgarians and Albanians. The artisans constructed a variety of elements as part of the palace complex: "barracks, schools, an arsenal, a gun-powder factory and a mint". The palace was constructed as a two-story pavilion in the style of a Turkish kushk. It has western style windows which are often topped with an oval oeil-de-boeuf. The French architect and engineer Pascal Coste was employed to add the residential quarters for the palace servants and functionaries. On one side of the palace was a haush (courtyard) and on the other, were views of the pyramids and the Nile [1] [2].

In 1822, a fire destroyed the palace's wooden construction in a blaze that lasted for 2 days. Later, Muhammad Ali had the structure expanded and elaborated upon with the construction of "a large marble fountain, columned stone terraces and porticoes, parterres of flower beds and orange groves, and even a menagerie containing a lion, two tigers and an elephant", a gift of the British Lord Hastings.

Two years later, in 1824, fire again damaged the palace after explosions of gunpowder. Muhammad Ali imported large slabs of marble from Italy to build a vestibule, staircases and corridors [3].

In 1825, English traveller Anne Catherine Elwood described the opulence of the palace, in particular its grand room that could offer dancing, and had deep niches for conversation and side rooms for music, reading, games and refreshment.

Muhammad Ali's official divan or audience hall, where the pasha received guests, contains a $1000 \mathrm{~kg}$ chandelier sent to him by Louis-Philippe I of France. Some of the paintings in the Pasha hall of the palace portray the receiving of foreign ambassadors.

The palace also contains the throne of Muhammad Ali Pasha that was a gift from the King of Italy [4].

The palace consists of a number of adjacent main blocks and several buildings, such as the justice chambers, private chambers and rooms dedicated to the staff of the palace. The palace consists of two floors and the palace begins with the main entrance which is covered by a portable marble pillar and leads to a corridor 

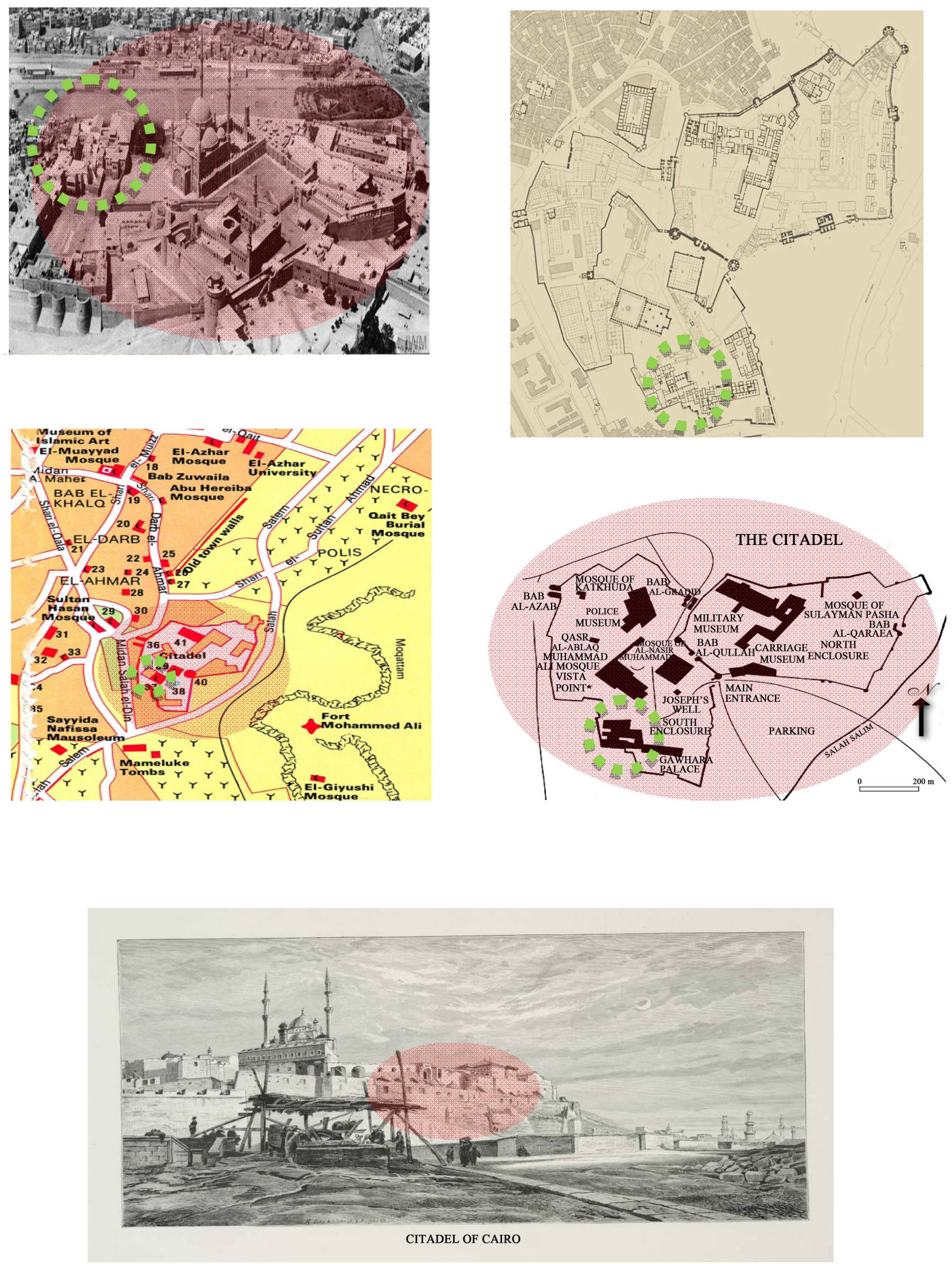

Figure 1. Maps and aerial views of the citadel of Saladin and the location of the Al-Gawhara Palace. 


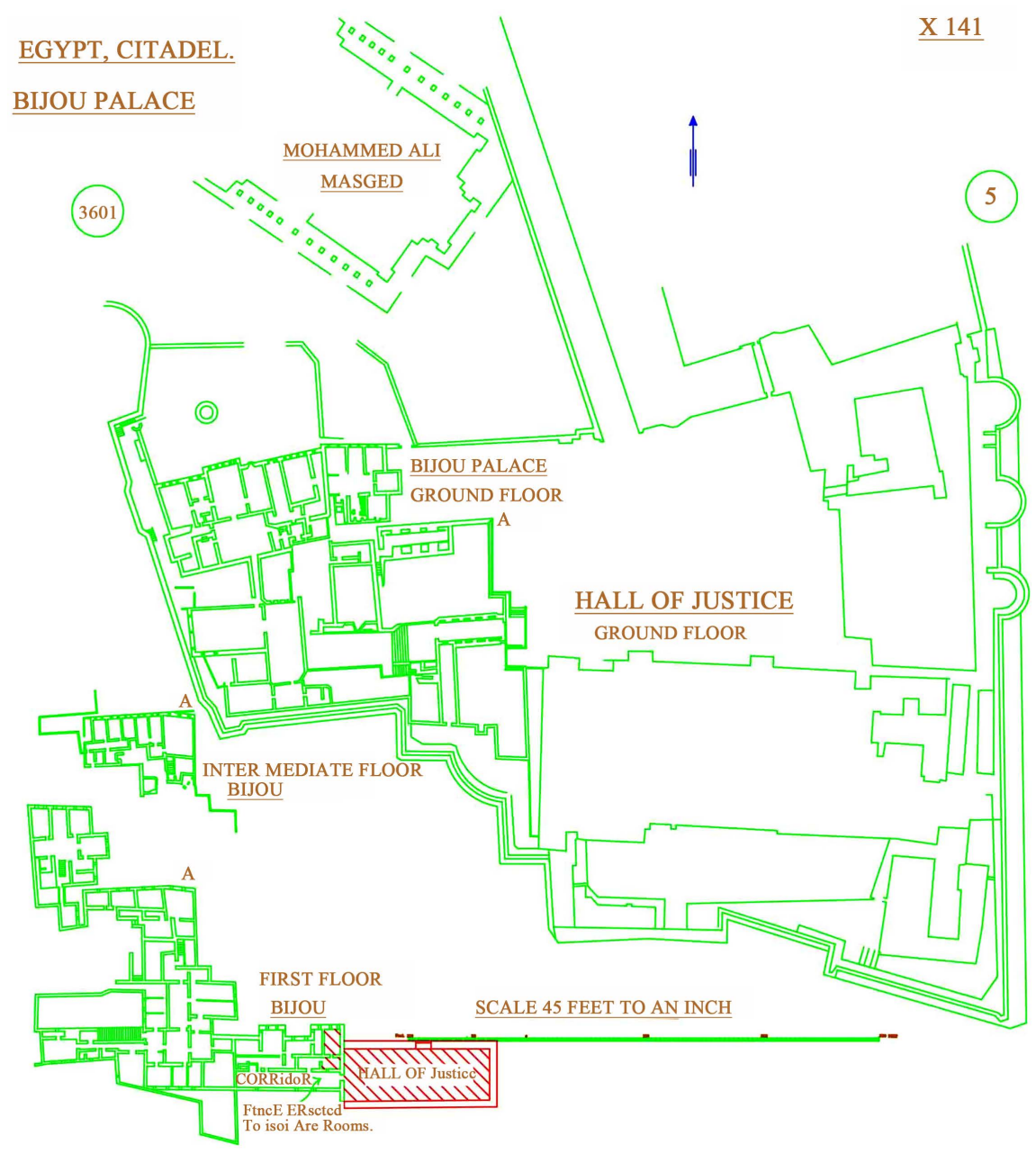

Figure 2. General layout of important buildings inside the Cairo Citadel, original plan.

that leads to the palace and reception halls. The receptions of Mohammed Ali and her Iwan supplement and two rooms are in addition to the Throne Hall, the largest halls of the Serail. From the reception hall we reach the sea jag by means of stairs and it contains two sections and the black garden because there are statues of the black Alabaster, and the suite contains a bathroom. It is known as the alpaster bath, while the second floor is the reception suite and leads to the guest cabins (Figure 3) [5].

The reuse and employment process is more suitable for buildings and historical areas that can accept any material changes in their original condition in order to suit their re-employment for the same old or new use, including "historical palaces". This approach includes more than one method of dealing with the state of urbanization and its scarcity so as not to allow any material change to existing, or to allow a weak physical change in order to connect electricity networks, sewage and water recharge, or material change in order to allow the employment of a new activity. This approach to dealing with the urban heritage through the rehabilitation and the employment of components of urban development specialists and urban planners in that it leads to the seizure of areas of the city 


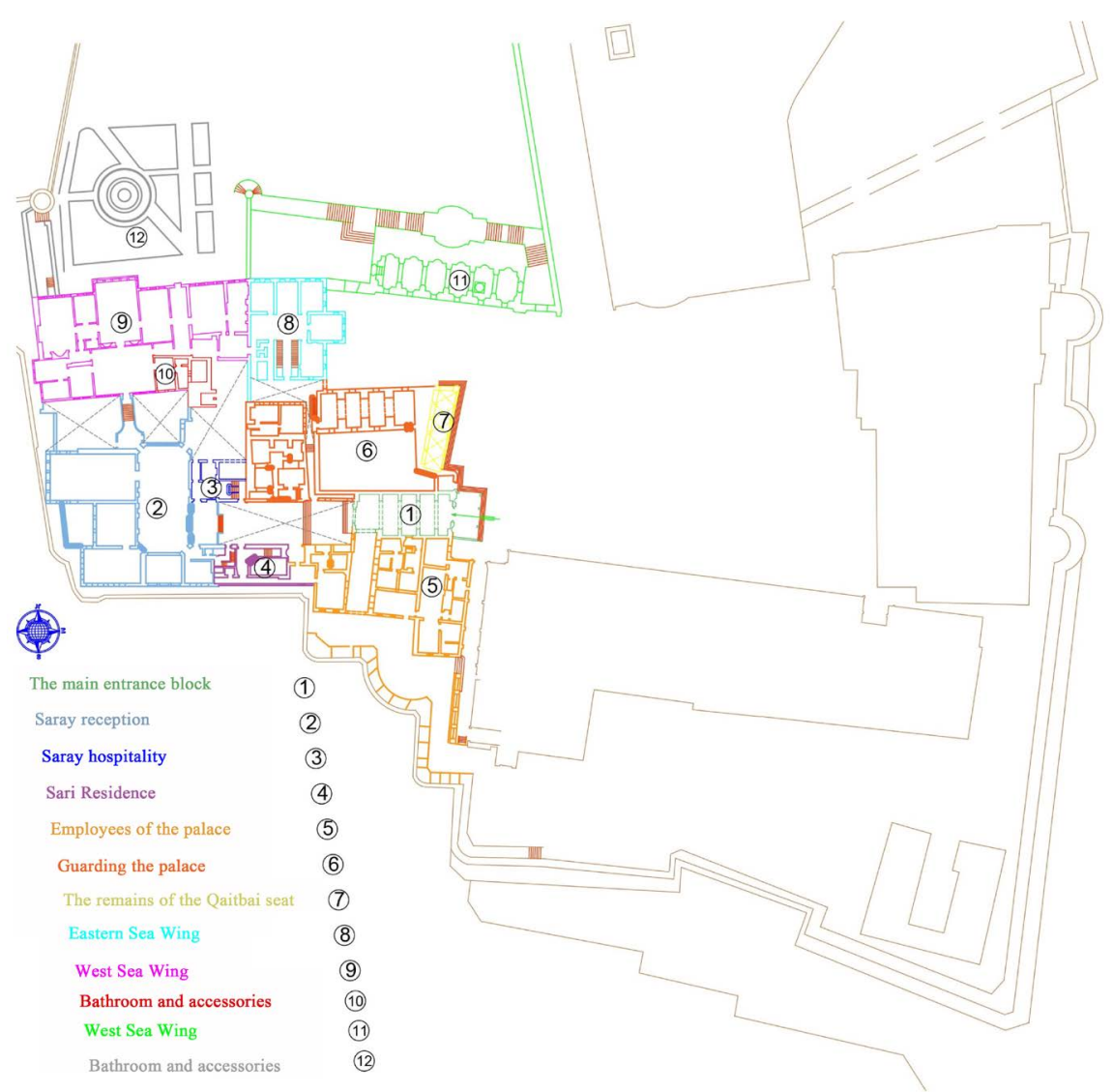

Figure 3. General layout of Al-Gawhara Palace in the Cairo Citadel, the present state.

outside the field of urban development and allows the integration of the development of old and modern architecture.

Rehabilitation of the building is the opportunity to modernize and make suitable for the time required of the rest of the way and give the building a new life.

The present research hypothesis includes 1) reuse and deliberate employment is the best way to preserve historic palaces; 2) the optimal choice of the function that suits the building and its application is through the foundations and criteria of correct scientific reuse and employment, and the application leads to avoid the problems that result from the re-employment is not studied and the foundations and rules of international conservation.

The study deals with the preservation of the restoration and re-employment of historical buildings with emphasis on "historic palaces" especially the shortcomings of the family of "Mohamed Ali" by monitoring and documenting the current situation and measuring the application of the foundations and international standards for re-employment, which help to:

1) To show the values of the heritage building of historical, aesthetic, artistic, functional and social values;

2) Permanent follow-up on the historic building by the users and users of the building in order to protect against infringements and exploitation for purposes that conflict with its historical and technical value by those who are outside the 
laws and regulations to achieve a high return that does not meet the high level of maintenance of the building.

We can summarize the benefits of current research in the following three points:

1) Demonstrating the importance of protection and revitalization of the "historic palace" and highlighting the importance of re-employment projects to ensure continuity of business Maintenance of this important architectural heritage, especially short-term works such as cleaning;

2) Highlight the aesthetic values of the historical palace, which leads to show and strengthen its artistic and historical value;

3) To create public sympathy between the impact and the public of the dealers, through the selection of suitable jobs such as the functions performed the building of the surrounding community;

4) Highlight the importance of retaining traditional patterns and the importance of integration and cohesion between the old and new urban fabric.

\section{Architectural Description of the Palace}

Al-Jabrati was mentioned in the incidents of $1228 \mathrm{AH}$, referring to the style on which the fortress was built (he proceeded to build another building with Rumi and built the most buildings of wood and built the highest before building the bottom) It is clear from the text of Al-Jabrti that Muhammad followed a new pattern of construction is different from what was widespread and known during the Mamluks, but Al-Jabarti not only mentioned the name of the Roman style, but briefly outlined the method of construction and advantages and disadvantages. However, the Rumi style was not developed by Muhammad as a pattern in the building. It has emerged since the Seljuk era during the 11th century and I moved with them to the Anatolian country. There were several stages and developed until it reached the final stage, which Muhammad Ali used in his building (Figure 3).

It is attributed to Mohamed on the entry of this model to Egypt, he mentioned Mubarak in his plans: (The first to enter the Roman buildings to the Egyptian homes is Aziz Muhammad Ali Pasha the Great, he brought teachers from the Roman and built him a transport (Figure 4) [6] [7].

\section{Facades}

Main façade of the Palace is the eastern façade where there is the main entrance and it is characterized as two different levels differ building material in each of them, we find the first level is built of stone and the second is built of pay, and this interface is not on one level where we find that the block of the portal stand out from the facade and separate them And the northern side of it has the remains of the neighboring Qaitbay seat (Figure 5).

\section{The Foundation Text}

Above the entrance held as previously stated in writing board in black on a red background text "Oh Brightening doors open for us the best door" and in 


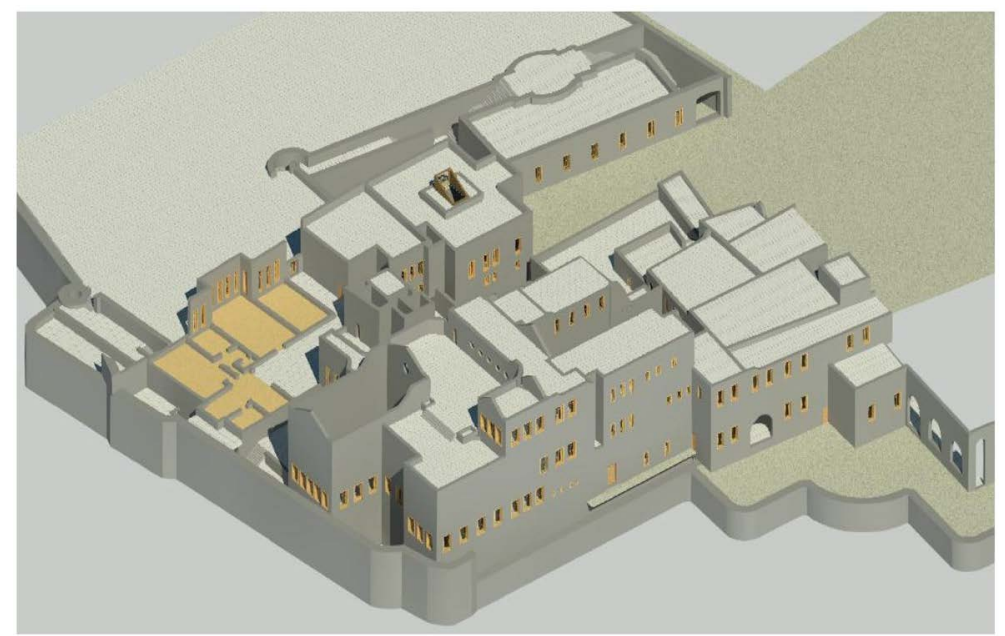

Figure 4. 3D Revit model of Al-Gawhara Palace in the Cairo Citadel.

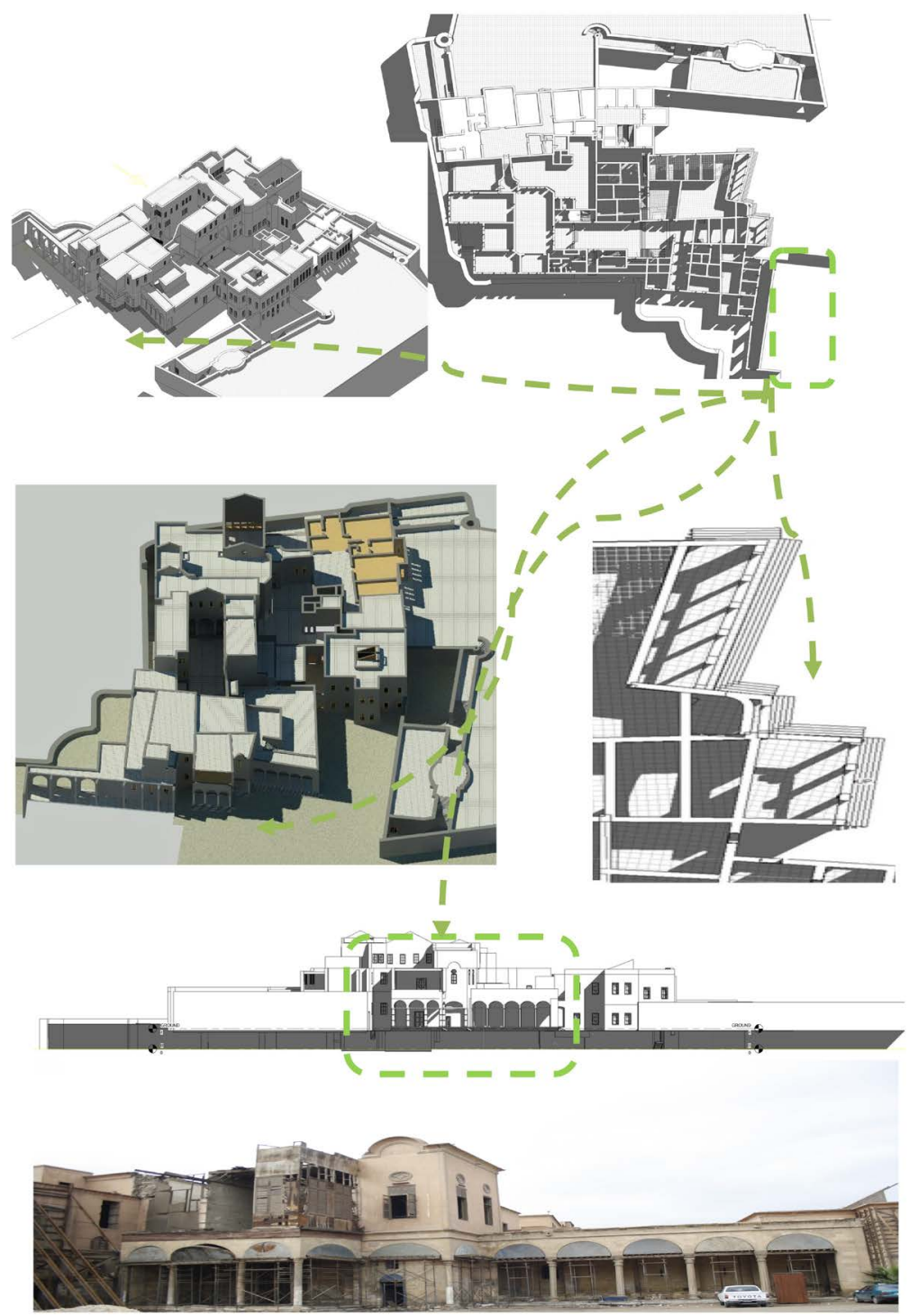

Figure 5. Main façade and entrance of Al-Gawhara Palace in the Cairo Citadel. 
the bottom line in a high $1228 \mathrm{AH}$.

Third: Interior Design of the Saraya

The Saraya building is derived from the Ottoman style of the division of houses, especially the high-end ones, to Salmlek and Hamralk. The development and refinement of the plan of the European palace system in the eighteenth century $\mathrm{AD}$ resulted in the elements of a new architecture, then a century later, such as the courtyard and the reception hall and pavilions especially Pasha and Harem. Otherwise, the palace is of little importance at the architectural level, but its decoration, which is transferred from the European models, is a direct indication of the role of these models in their influence on the tastes of the high class at the time.

\section{1) Main Courtyard}

This courtyard is in the middle of the two wings of the palace. It is worth mentioning that the idea of the pavilions in Islamic architecture and it is a basic unit inspired by the whole of the Islamic faith is characterized by the courtyard as the link of the distinctive and distinctive of all Islamic buildings, whether religious or residential is the symbol of life and the center of attraction for all the elements that wrap around and overlooking (Figure 6) [8].

\section{Reception}

It enters the reception halls from the above entrance and consists of two parts:

The First: The main reception area is topped by a second floor connected to the guesthouse (Figure 7).

\section{Second: The Sea Reception Suite (Figure 8)}

The first part of the building was used as a design unit based on a large hall (hall), which consists of units consisting of interconnected rooms (Al-Kushah Hall, Al-Keswa Hall), other larger rooms, The walls of this lobby are characterized by the presence of gardens or income used in the development of lamps and antiques.

\section{2) Reception Hall}

It is a rectangular chamber that is opened with each rib or each door rinse and has a length of about $10.60 \mathrm{~m}$.

\section{Accessories for the Reception Area}

\section{First: Al-Kushah Hall}

\section{Room Planning}

This room is accessed by the door which is rinsed to the south-west of the reception hall, where we find a rectangular room about 12 meters long and 7.30 meters wide. The northern side of this room begins with a door opening leading to a hall attached to the courtyards and the rib of this rib opens onto the open courtyard, It has 4 windows overlooking the southern walls of the royal square of the castle to the south, while the western side opens with 3 windows overlooking the city from the west.

\section{Second: The Cladding Hall: Room Planning}




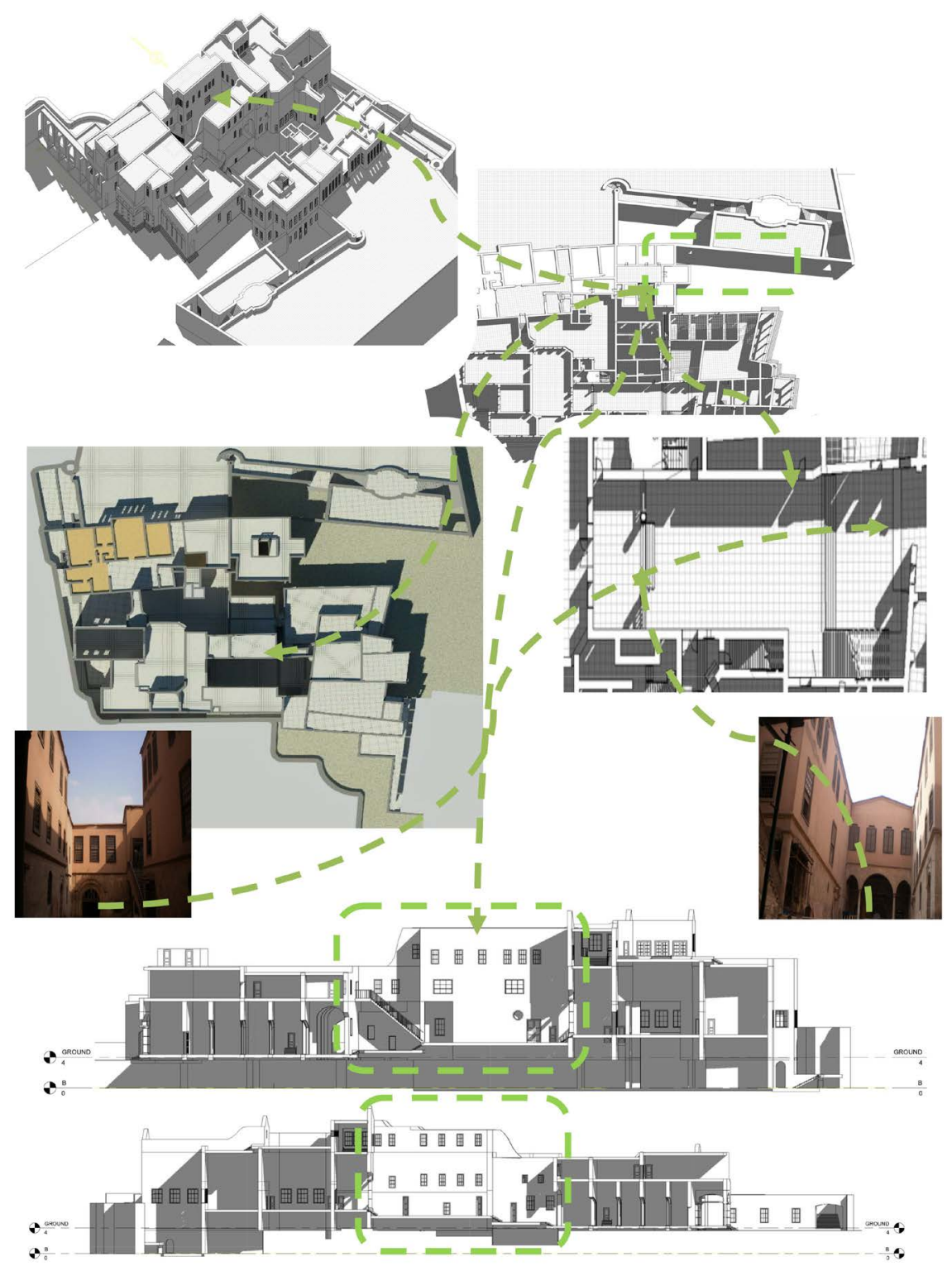

Figure 6. Main courtyard of Al-Gawhara Palace in the Cairo Citadel.

It is a rectangular hall, which is offered from the east to the west, $8.75 \mathrm{~m}$ and its length from north to south, $9.35 \mathrm{~m}$.

\section{Third: Throne Hall}

Is a large hall known as the throne hall or Farmans reached by the middle door labeled (God is reconciled), This room is the largest room in the palace walls, the remains of inscriptions and the roof in the shape of an oval with gilded inscriptions representing weapons and musical instruments with a golden wooden bench in the middle of which is a collection of fruits, which overlooks Salahuddin Square, including a view of Cairo and Fustat and pyramids

\section{Fourth: Maritime Reception Pavilion}

We reach this wing through the door which is located in the north-west corner of the reception hall, where this section leads to a cross-sectional crossing 


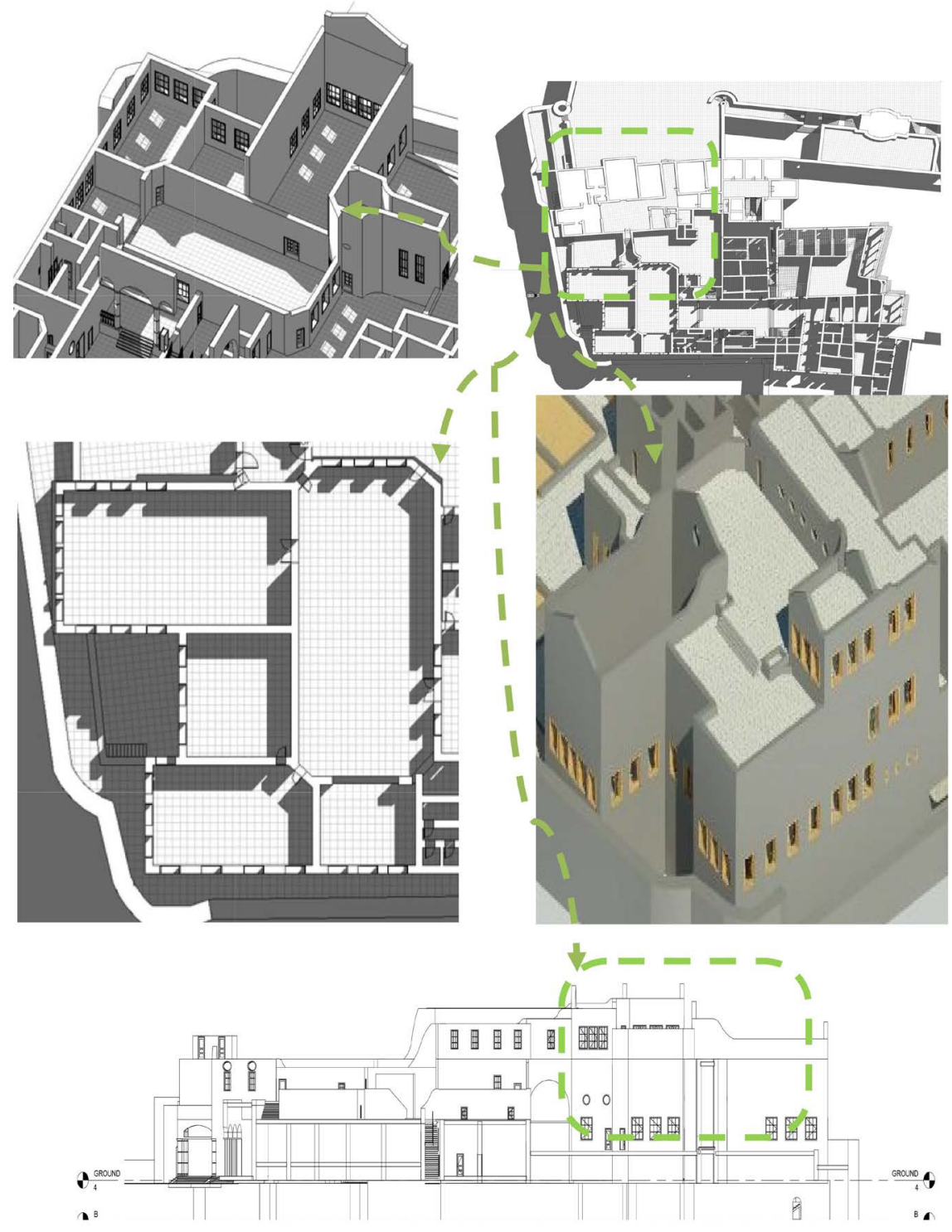

Figure 7. First part of the reception of Al-Gawhara Palace in the Cairo Citadel.

at both ends of which leads to an open courtyard in the middle of the buildings of the guest houses and the palace bathroom. The western door leads to an open courtyard in the middle of the throne room. The middle of the northern rib of these vertices, we find an ascending staircase that ends with a door opening leading to a rectangular hall. On the right and left of the stairs are two oval windows, which are decorated with glass with gilt-like curtains. The ceiling of the stairway is in the shape of a non-embossed letter and decorated with geometric areas and ribbons. Varying degrees, large parts of the sea wing have been destroyed for reception [9] [10].

\section{West Wing}

The former door leads to a rectangular area extending from the east to the west $12.20 \mathrm{~m}$ and width from north to south $10.30 \mathrm{~m}$. The middle of the wings of the sea wing and its northern rib leads to a rectangular chamber with five walls 


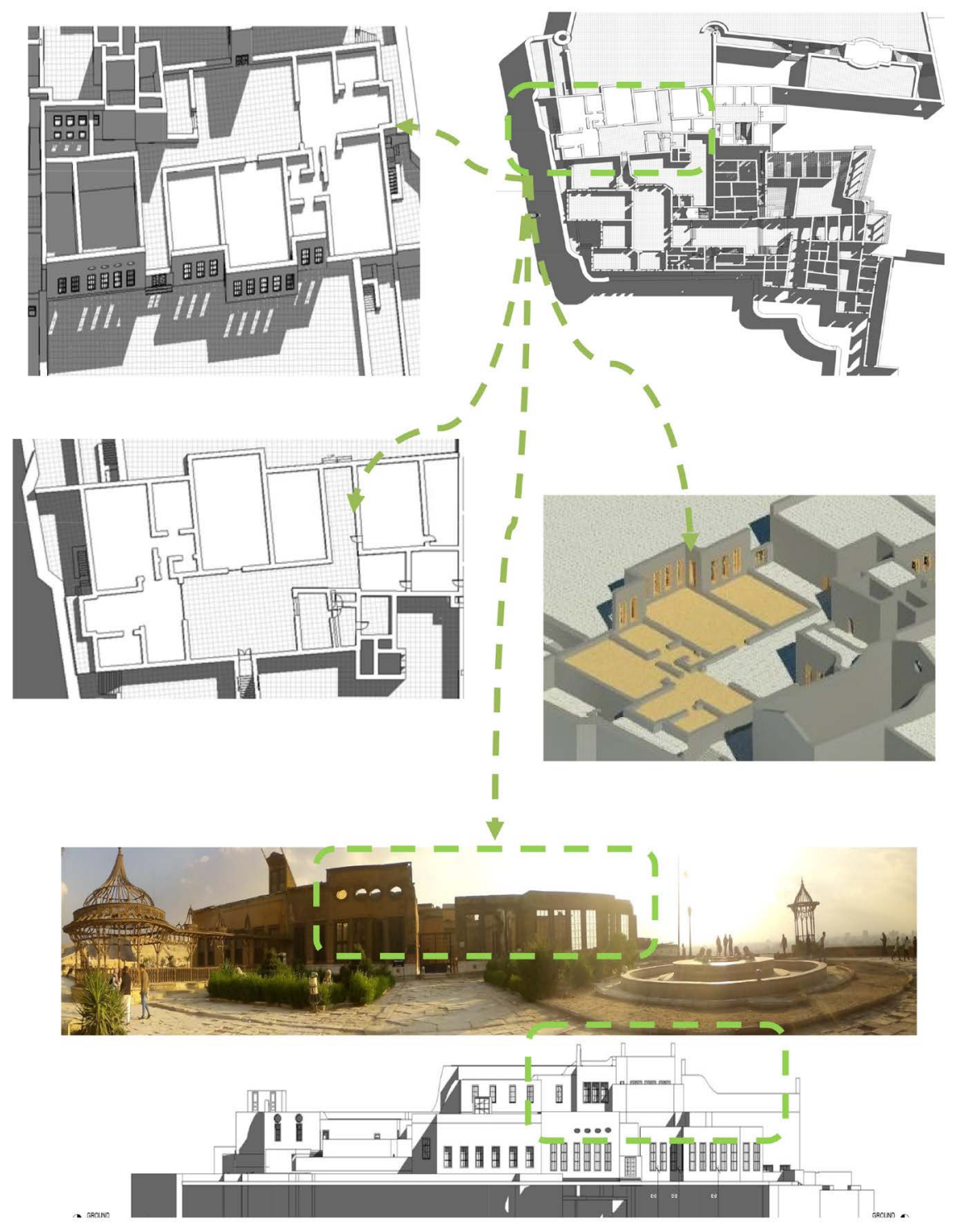

Figure 8. The maritime reception pavilion in Al-Gawhara Palace in the Cairo Citadel.

opening in the prominent part of the northern facade overlooking the black garden. East and West opens in each side of the door leads to a rectangular room, and the eastern rib opened a door on the axis of the previous door, which leads to the corridor between the eastern sea wing and the western sea wing.

\section{The Bathroom}

The southern opening of the eastern rib of the former hall leads to a rectangular chamber that opens west of the northern side to the east. It leads to the bathroom. The opening of the opening of the door is 1.20 and its height is 2.10 $\mathrm{m}$. It closes two wooden doors and leads to a semi-rectangular hall with its northern north rib. Its floor is covered with slices of Egyptian marble, and its ceiling is decorated with pieces of stained glass that allow light to enter. It is a model of the Turkish baths that were prevalent in that era [11] [12].

\section{Cold Bathroom Lounge}


The opening of the door leads to a semi-rectangular hall with a northern side of $2.70 \mathrm{~m}$, a length of $4.90 \mathrm{~m}$, a south of $2.10 \mathrm{~m}$, a west of $5.50 \mathrm{~m}$, and a rectangular door of $1 \mathrm{~m}$ leading to the toilet. The eastern side of the bathroom has a width of $1.5 \mathrm{~m}$ and a depth of $80 \mathrm{~cm}$. The Oriental bathroom has a square dressing room.

\section{Shower Room}

Is a rectangular room whose dimensions are from the south to the north 4.85 $\mathrm{m}$ and from the east to the west $3.20 \mathrm{~m}$ to the north by the entrance of a depth of $1.50 \mathrm{~m}$ The floor of the shower room is about $15 \mathrm{~cm}$ in height and the entrance is crossed by the entrance floor of the entrance Oval basin for marble shower white marble carved from one block, The eastern side of the shower room is surrounded by an oval-shaped marble basin imported from Beni Suef quarries [13].

\section{Toilet}

In the northern side of this hall opens a rectangular door $1 \mathrm{~m}$ wide, leading to the toilet. It is rectangular. The area is $2.85 \times 1.30 \mathrm{~m}$. Its eastern side occupies an empty seat and the walls of the toilet are covered with marble slabs.

Eastern Sea Wing (Figure 9)
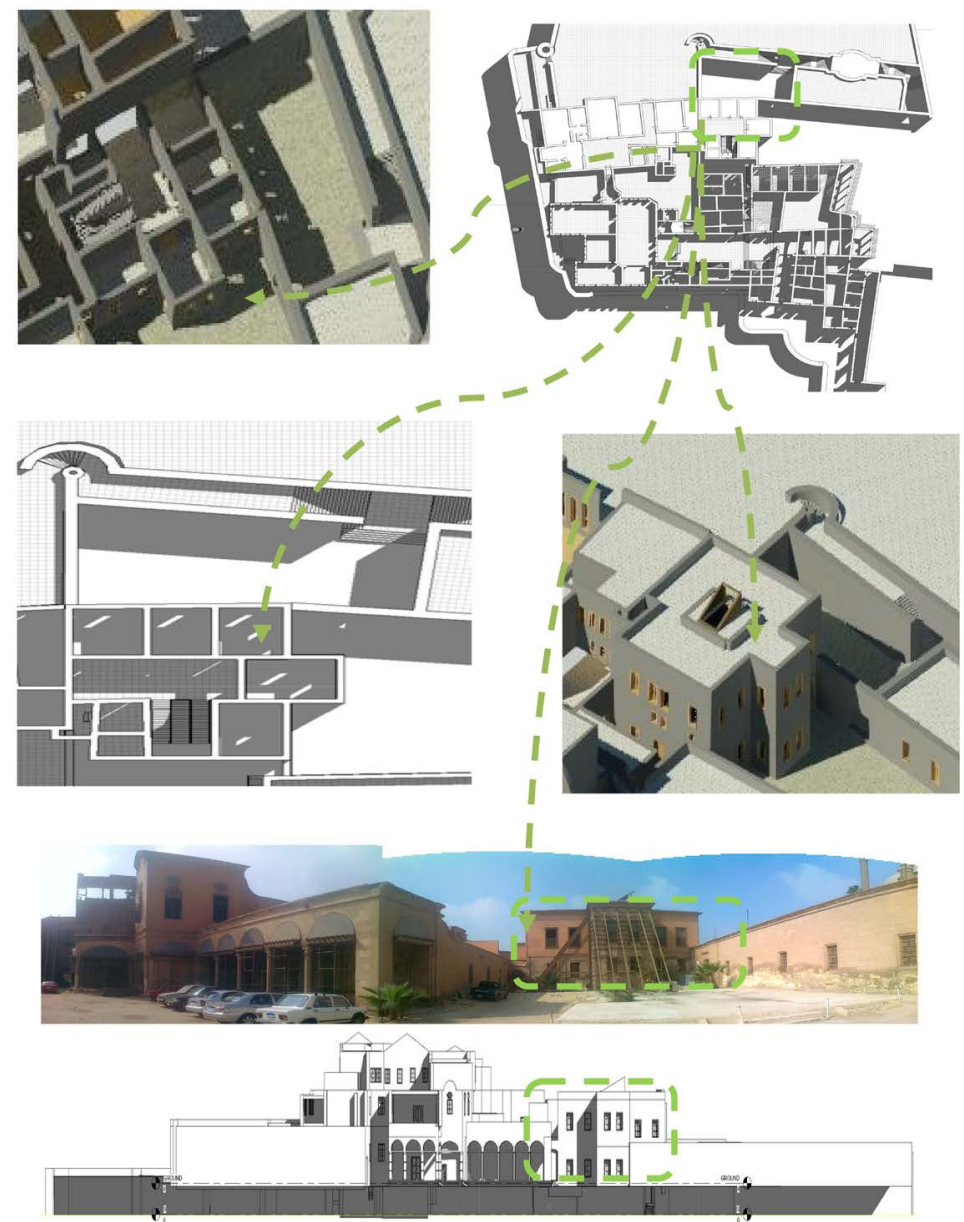

Figure 9. The eastern sea wing in Al-Gawhara Palace in the Cairo Citadel. 
This wing is separated by a passage of $16.80 \mathrm{~m}$ and a width of $3.60 \mathrm{~m}$. Its northern end ends with a door leading to the Black Garden. The eastern side opens two doors at the southern end of this rib. This section leads to a rectangular chamber of 12.55 meters long. In the eastern side is a door opening that leads to a rectangular lobby and opens on its western side a door opening that leads to a rectangular hall. The eastern side of this lobby has some prominent pillars of the walls, while the rib the south is only crumbling. It may have led to small annexes that may have been kitchens located behind the western sea wing bath. On its eastern side, two doors open into two small rooms, and its northern side opens wide to a large hall that still retains a part of the roof. The lounge is also a square room. It is worth mentioning that this Iwan and the two squares next to it in this wing and the corresponding in the south of the hall are other floors with rooms and other annexes to the palace. This is unlike the case in the western sea wing, which was built directly on the ground [14].

\section{Saraya Residence (Figure 10)}

This unit consists of a main unit which is known as the upper throne room where this hall consists of a hall open by Iwanan in the north and south. In addition

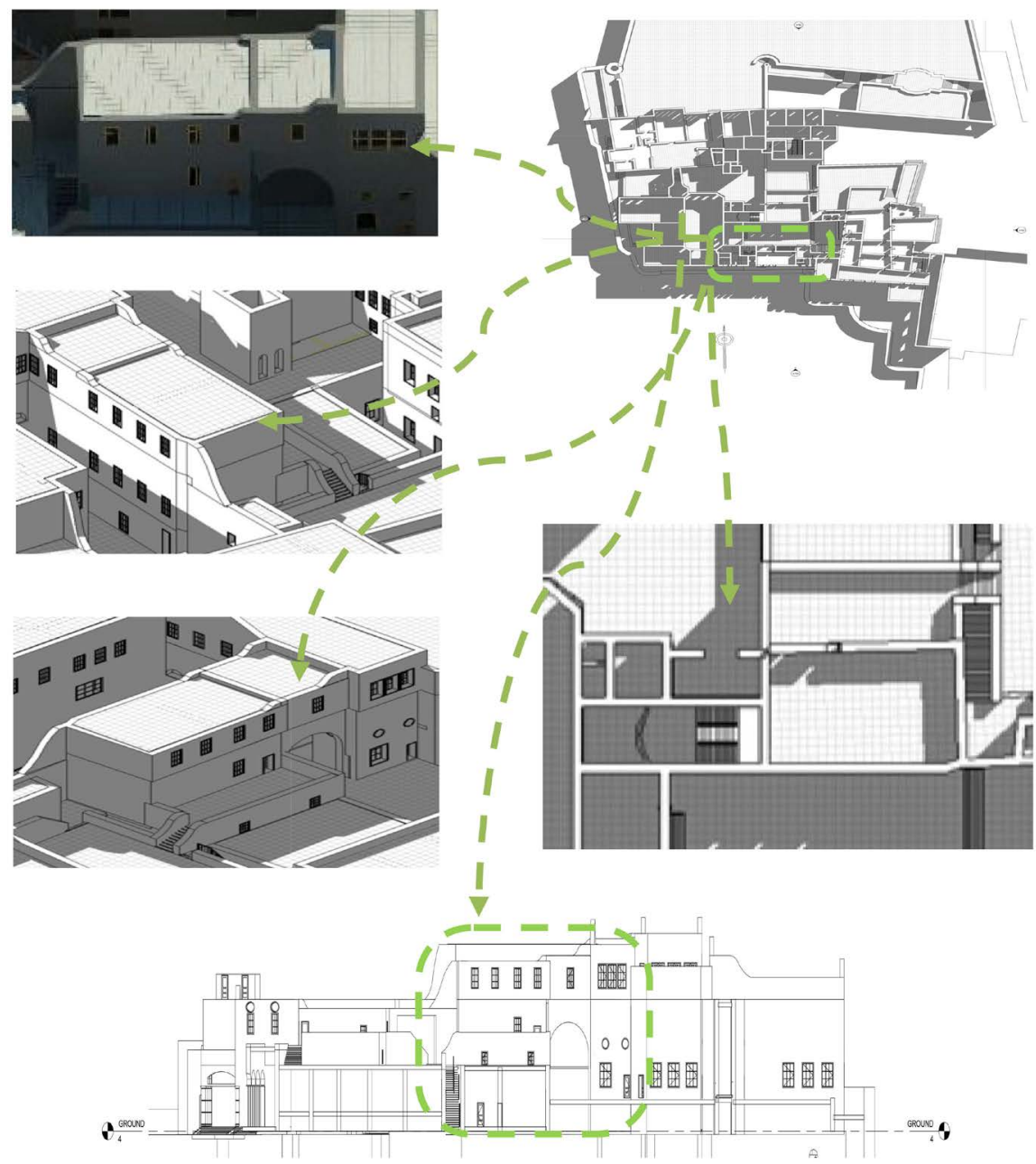

Figure 10. The Saraya Residence in Al-Gawhara Palace in the Cairo Citadel. 
to this main unit there are other units, some of which are independent like the bedrooms and some of them branch out from the southern unity of the main unit such as the reception hall Upper and Gift Wing [15] [16].

\section{The State of Preservation of the Palace}

\section{Structural System}

The overall structure system of Al-Gawhara Palace consists of, superstructure, substructure, structure of foundation and foundation medium.

The superstructure comprises the storeys situated above the ground floor; first floor to the second floor.

The vertical component of the structural system of the superstructure consists of structural multiple leaf multiple leave masonry bearing walls, disposed along the four axes: on the longitudinal direction (axes "1", "2", "3", and "5"); on the transversal direction (axes "A", "B", "C" and "E"). The horizontal component of the structure consists of wooden slabs and beams are reinforced and supported by steel bars (Figure 11).

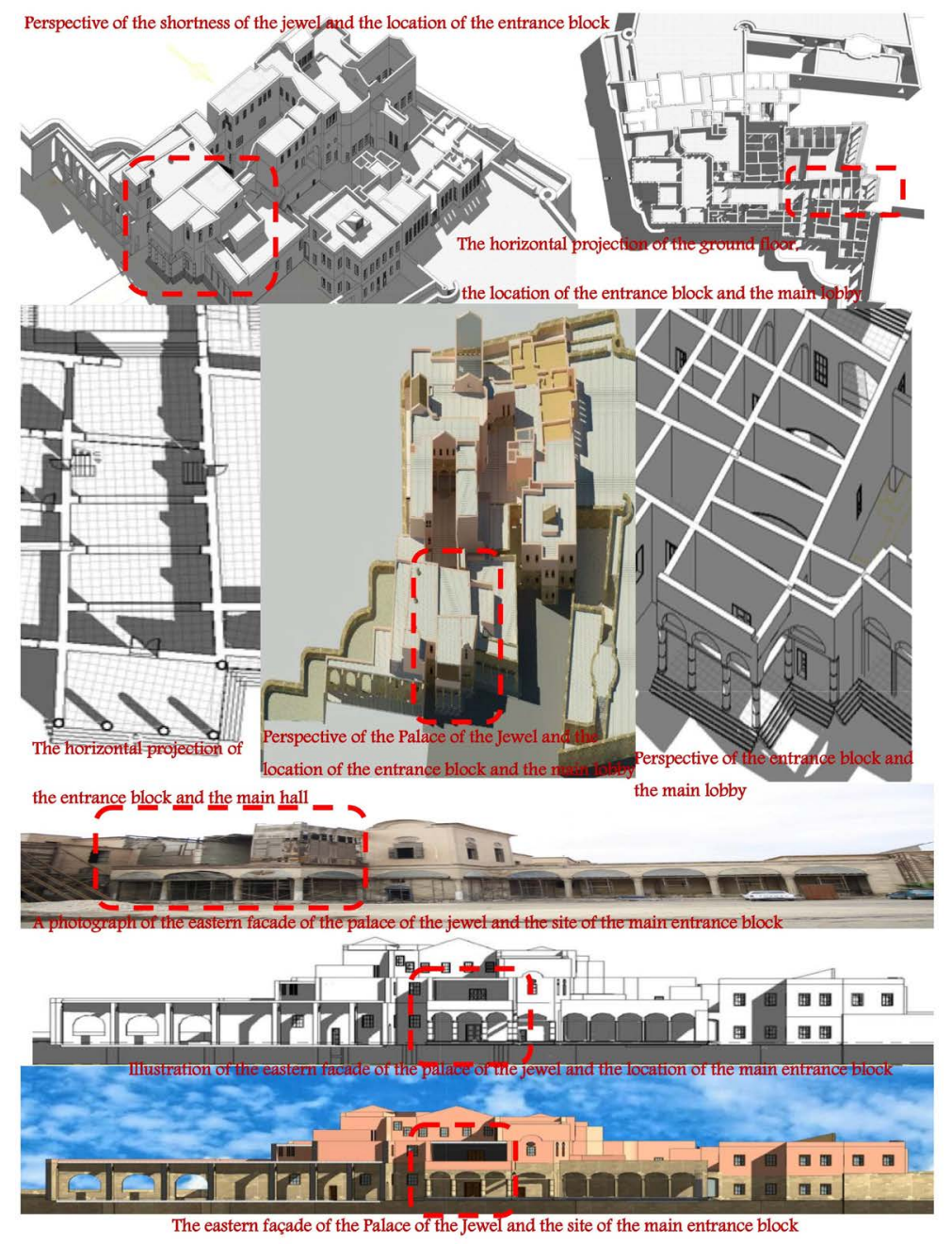

Figure 11. The eastern façade of the palace and the site of the main entrance. 


\section{Structural Deficiency}

The main structural deficiencies of the vertical component of the structural system are:

The superstructure and substructure of the palace has suffered considerable damage due to extensive cracking associated with bearing foundations displacements and movements undergoing a shear failure accompanying with large displacement both towards to the western and northern directions as well as the center of the palace [17].

Cracks widths were $30-100 \mathrm{~mm}$ and exhibiting periodical widening. The cracks had a preferential orientation in all principal directions, which includes typical views of major cracking in the masonry walls and foundations. Such effects were attributed to earthquakes damages, permanent deformations and large settlement of the bearing old reused foundations of the previous underneath palaces and houses in the same place due to overloading, natural wear of construction materials and the construction history of the complex (Figure 12).
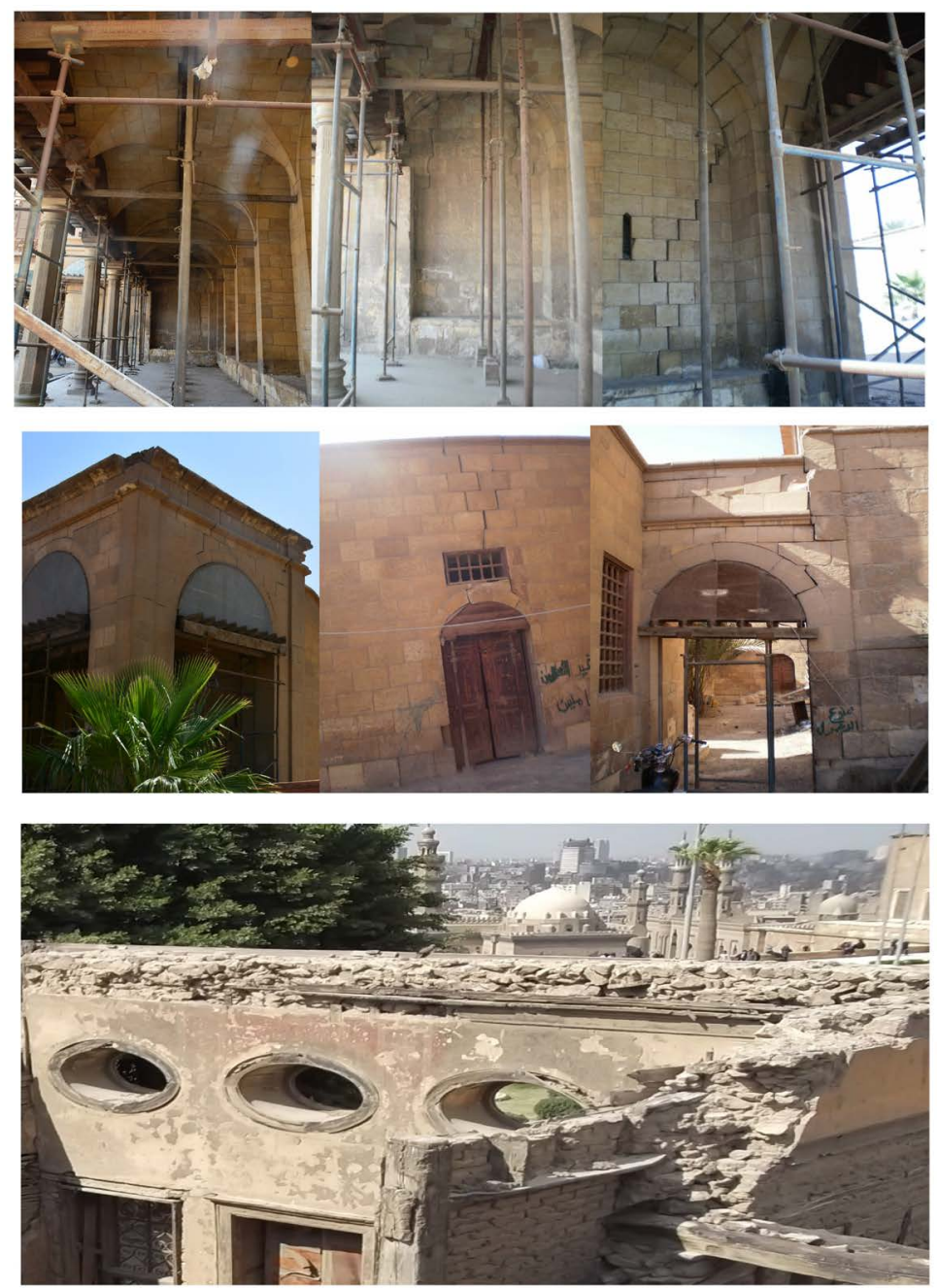

Figure 12. In and out of plane deformations and cracking pattern in different structural elements of the palace. 
Irregularities in disposing door and window openings, together with the variability of the dimensions of these openings (both on " $\mathrm{L}$ " and " $\mathrm{T}$ ”).

The fact that the structural wall horizontal section areas differ on the two main directions of the building.

There are also irregularities of the structural walls horizontal sections, at each storey, on the vertical direction;

The structure of the foundation consisted of continues stone cyclopean walls type of approximately $2-2.5 \mathrm{~m}$ height, beneath all the substructure walls.

At the beginning, there was only information from the time press which claimed a bad foundation medium.

1) Old Sleeping Suite and Turkish Bath

a) Remains of wood floors and walls remain for the bedrooms in Cairo, while the walls and ceilings are completely destroyed;

b) Remains of walls of stone, brick and wood floors appear;

c) The walls of a new wall around the sleeping wing area were completely contradicted with the shape, nature and history of the old building and the entrance wall of the area only.

2) Turkish Bath

a) The walls, the floor, the Turkish bath, the toilet, the basin The marbles of marble and marble are scattered with cracks and lichens;

b) The roofs are worn and worn out and have many fractures and cracks, as well as the glass ceiling and are covered with soil and debris.

3) Entrance to the Jewel Palace

a) Due to time and erosion factors, the whiteness of exterior and interior walls may be eaten with cracks, broken glass windows and poor condition of the main and side doors of the entrance;

b) To eat and spread licorice in marble and marble with walls, floors and staircase;

c) The surroundings of the entrance gate are grounded and none exist.

4) Wing Throne Room

a) Currently there are only walls without the roof of the wooden truss that fell, eaten, burned and embossed and decorated by the side walls;

b) Crises and moisture are common in the walls;

c) The area adjacent to the hall is a layer of dust and remnants of old dilapidated buildings;

d) Wall mirrors are broken and most of them are not visible and show only their places;

e) Floors are rickety.

5) Wing of the Throne Area (Currently)

a) Surface cracks of time and earthquake in 1992;

b) The presence of water filters in the adjacent walls for the presence of modern protection courses;

c) There are fractures in the columns and walls, and the doors of wooden doors are damaged and dust accumulates on them; 
d) External walls show vertical cracks and spray water, whitewashed paint and paints;

e) There are areas adjacent to the throne and adjacent courtyard area with wooden, metal and crucifixion frames for the walls and walls affected by the earthquake and other time factors.

Fry Tiles and Spray Water with Walls

6) Wing of the Throne and the Throne of the Kaaba (Currently)

a) Located in the vicinity of the throne throne and the floors are worn and the walls are broken;

b) Wall paints and good pleasing.

7) Hall and Sleep Hall Hall Gifts (Currently)

a) External walls with vertical cracks;

b) Water courses are renovated with ceramic tiles, ceramics and modern sanitary equipment.

8) Al-Arayes Palace Suite

a) One of the most affected areas of the earthquake in 1992 and has many parts with swings, supports and reinforcements and new and dangerous cracks in the roofs and walls;

b) The internal and external walls are in poor condition and are filtered for water, bleaching, bleaching, and accumulation of waste and dust (Figures 13-15).

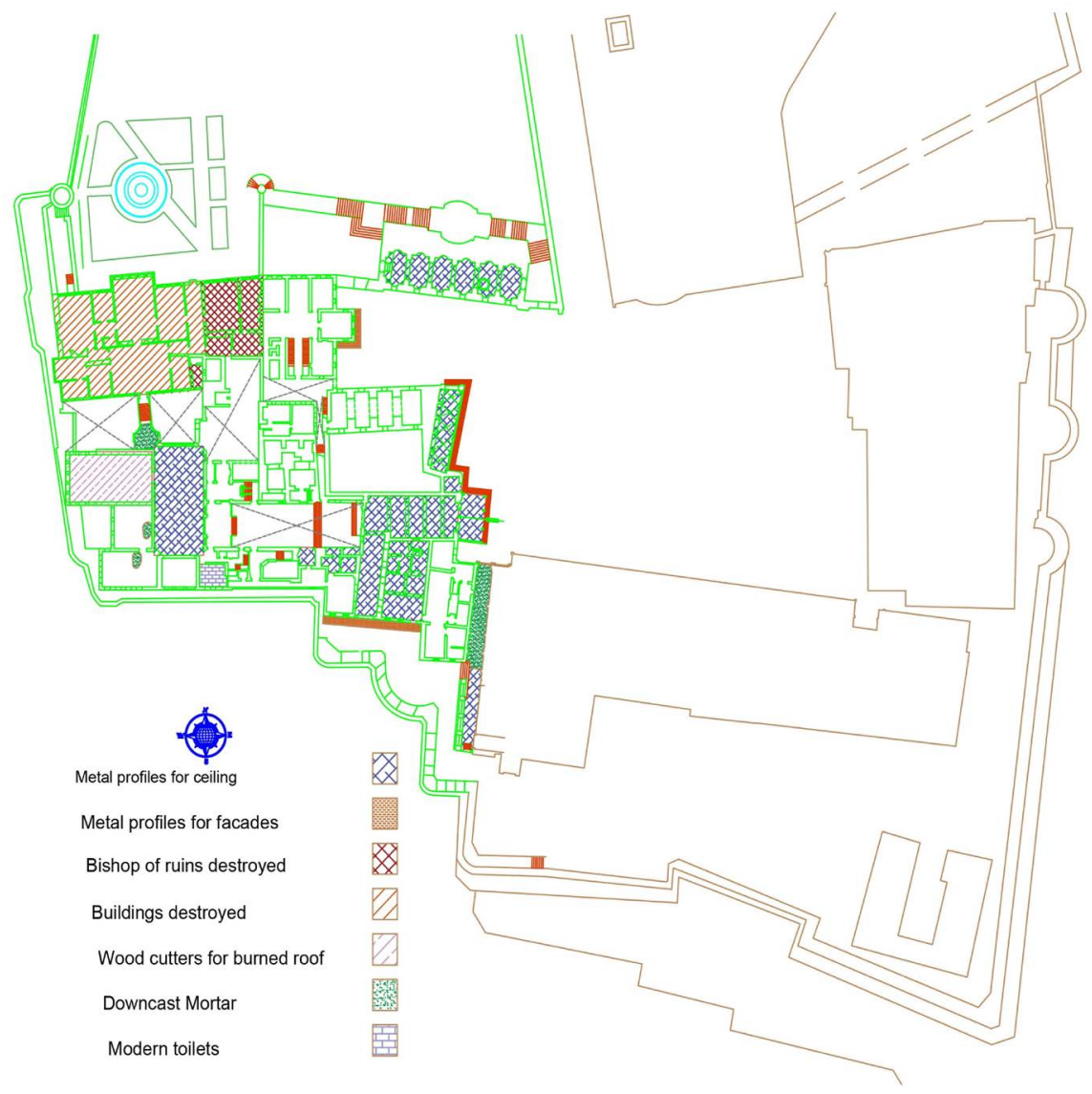

Figure 13. Al-Gawhara Palace, present state of preservation. 


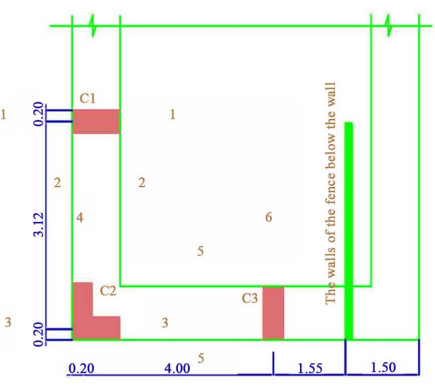

(3624)
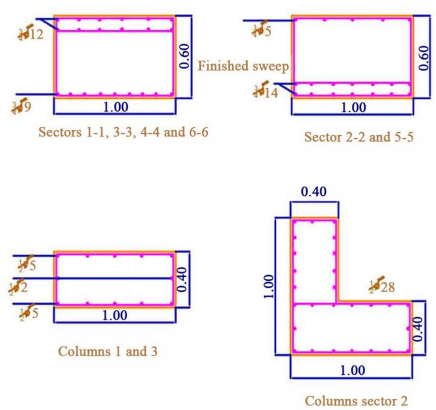

$\mathrm{SC} 1.20$
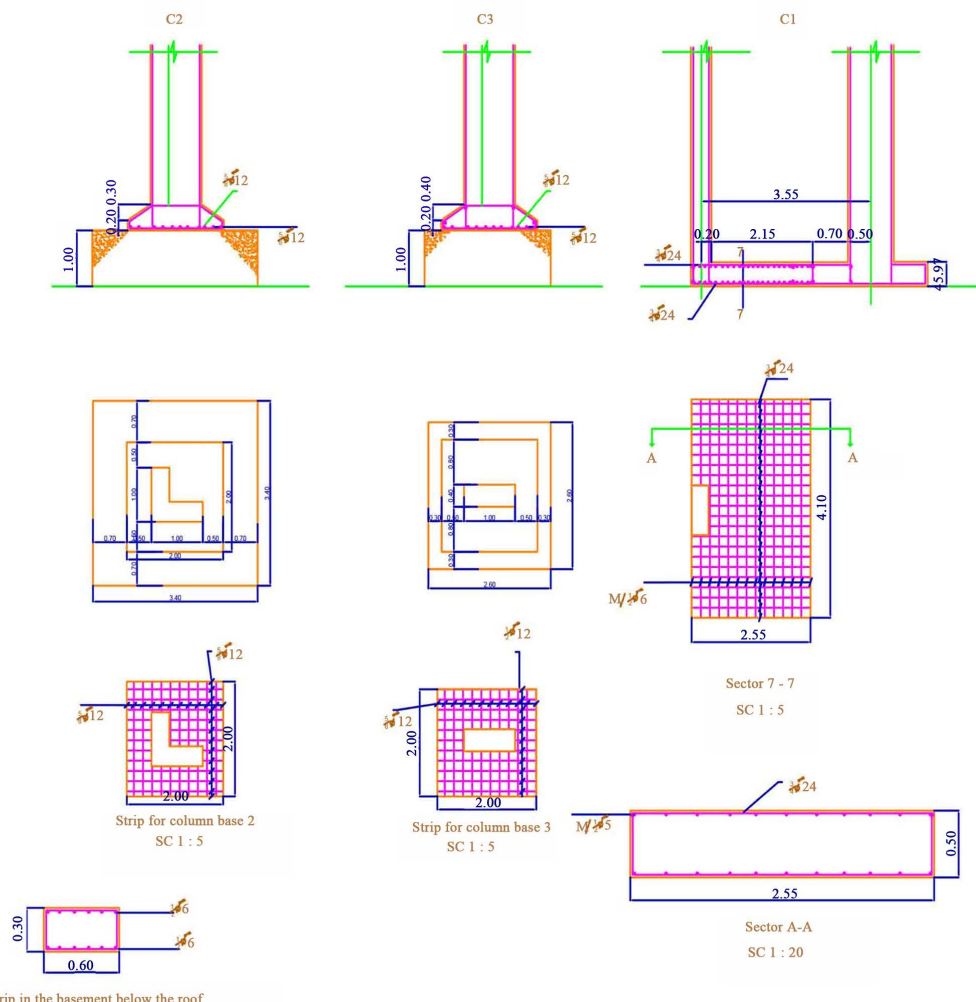

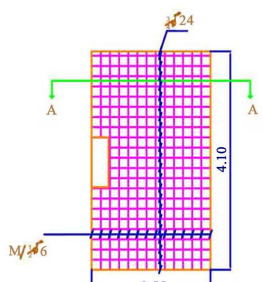

Sector 7 - 7
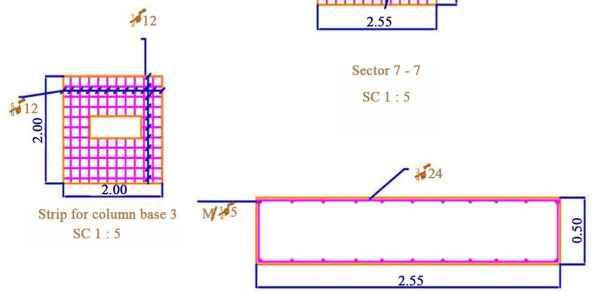
Sector A-A $1: 20$

Figure 14. Foundations systems (wall footings and base isolated footings) of Al-Gawhara Palace.

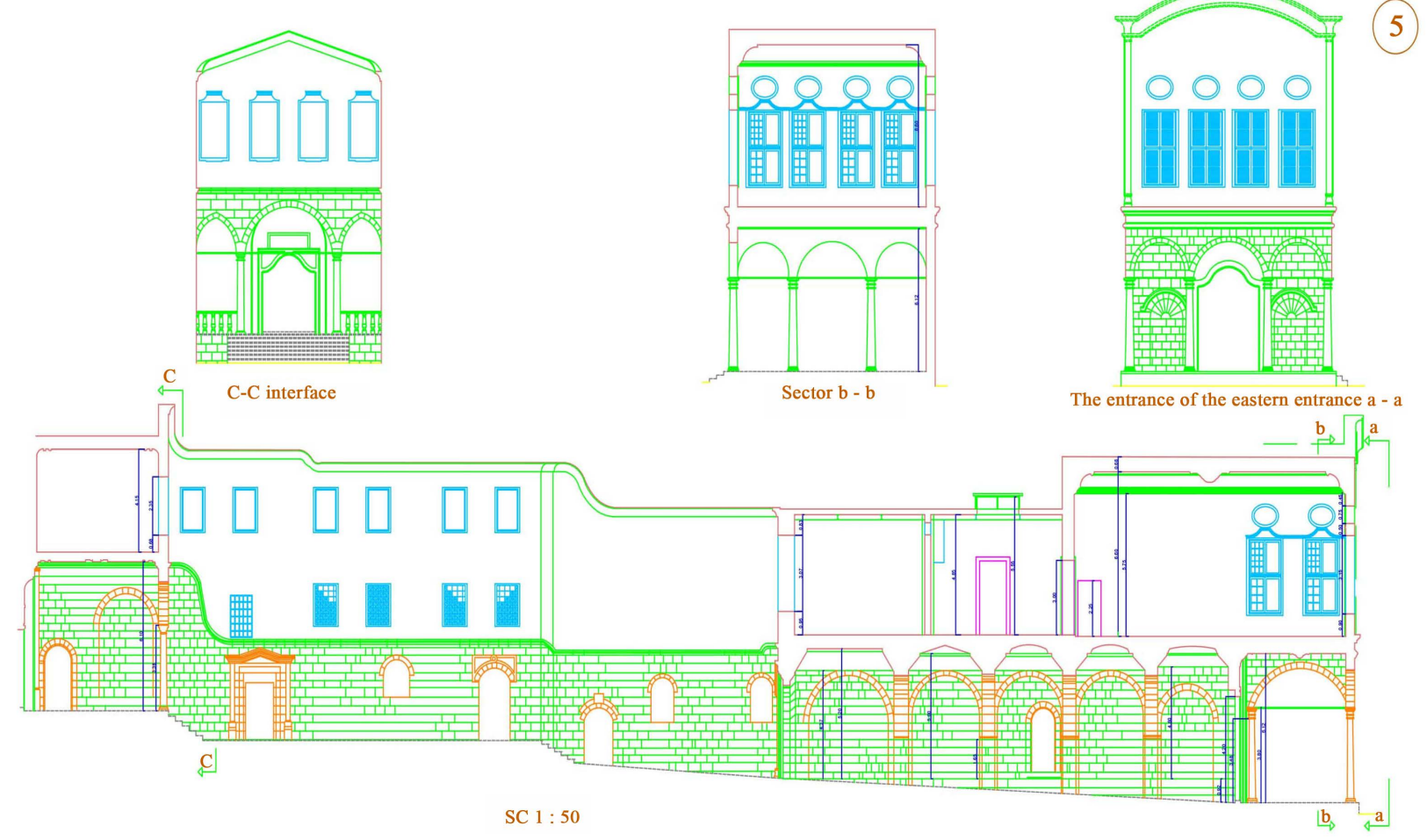

Figure 15. Longitudinal cross sections and some facades of the eastern entrance and court (1) of Al-Gawhara Palace. Scale 1:50. 


\section{Characterization of Construction and Building Materials}

\subsection{Fired Brick}

\section{X-Ray Diffraction Analysis}

The identification of the most probable phases is carried out using PANalytical computer certified program "with the aid of the International Center of Diffraction Database (ICDD) received with the X-ray diffraction equipment X'Pert High Score Software 2006-Licensed modules: PW3209. PDF-2 Database/CDRelease 2005-Type No. 943050001611. X’Pert Pro PANalytical-Manufactured by Panalytical B.V Co., Netherlands (ISO 9001/14001 KEMA-0.75160) [18].

The study sample consists of medium-sized quartz crystals. The sample floor is composed of iron oxide and some other dark metals (Diopside) as shown by XRD and thin section analysis of the sample. There are no traces or evidence of apparent damage to the sample of the studied bricks. Table 1 summarizes the chemical composition of the fired brick (Figure 16 and Figure 17).

Tables 2-4 summarize the mechanical properties of the fired brick building material (Figure 18).

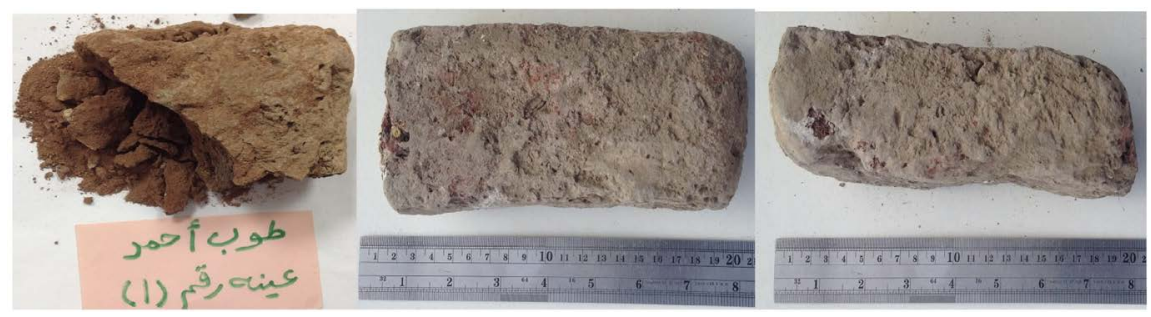

Figure 16. Some collected fired brick samples from Al-Gawhara Palace.

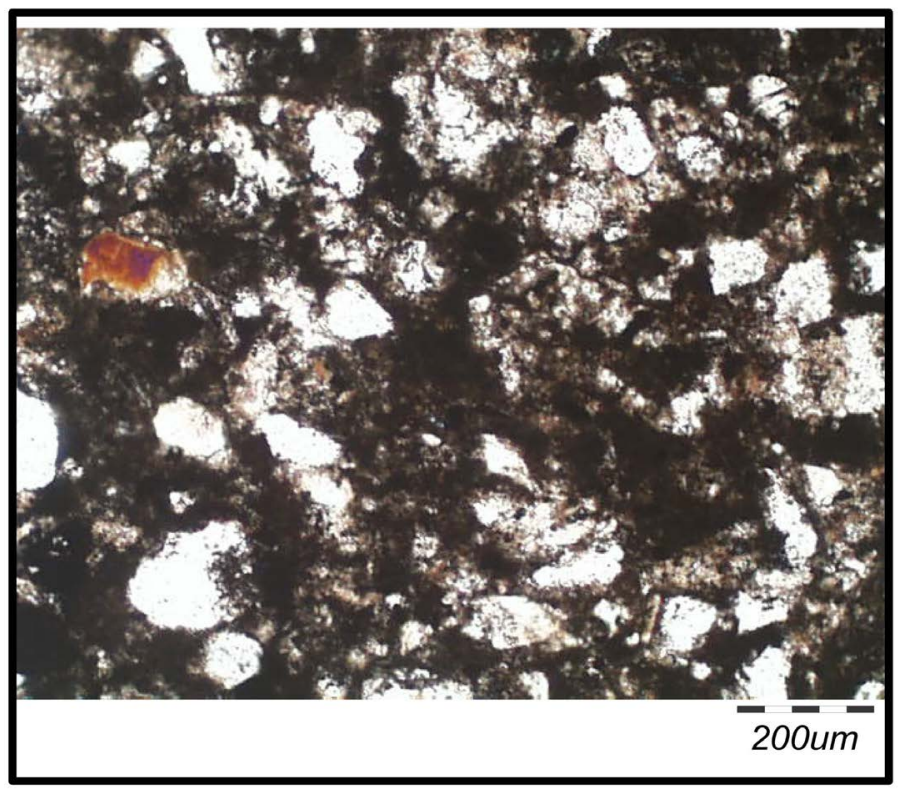

Figure 17. Thin section photomicrograph of the sample submitted by red Brick (XPL, 10). 

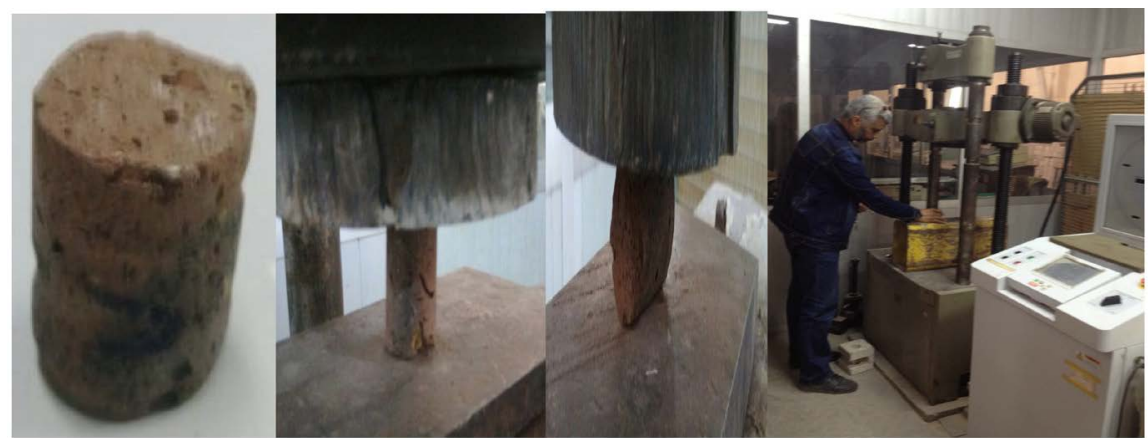

Figure 18. Some collected fired brick samples from Al-Gawhara Palace.

Table 1. Chemical composition of the fired brick.

\begin{tabular}{cc}
\hline Compound Name & Chemical Formula \\
\hline Quartz & $\mathrm{SiO}_{2}$ \\
$\mathrm{Fe}_{2} \mathrm{O}_{3}$, iron(III) oxide & $\mathrm{Fe}_{2} \mathrm{O}_{3}$ \\
Albite & $\left(\mathrm{Na}_{0.98} \mathrm{Ca}_{0.02}\right)\left(\mathrm{Al}_{1.02} \mathrm{Si}_{2.98} \mathrm{O}_{8}\right)$ \\
Anatase & $\mathrm{TiO}_{2}$ \\
Diopside & $\mathrm{CaMg}\left(\mathrm{SiO}_{3}\right)_{2}$ \\
Sylvine, syn & $\mathrm{KCl}$ \\
Hydrobiotite & $\mathrm{K}(\mathrm{Mg}, \mathrm{Fe})_{6}(\mathrm{Si}, \mathrm{Al}, \mathrm{Fe})_{8} \mathrm{O}_{20}(\mathrm{OH})_{4} \cdot 4 \mathrm{H}_{2} \mathrm{O}$ \\
\hline
\end{tabular}

Table 2. Compressive strength of the fired brick from Al-Gawhara Palace.

\begin{tabular}{cccccc}
\hline Sp. No. & Weight $(\mathrm{g})$ & $\begin{array}{c}\text { Average Measured } \\
\text { Dimensions } \mathrm{D}{ }^{*} \mathrm{H}(\mathrm{mm})\end{array}$ & $\begin{array}{c}\text { Ultimate } \\
\text { Load (N) }\end{array}$ & $\begin{array}{c}\text { Compressive } \\
\text { Strength }\left(\mathrm{N} / \mathrm{mm}^{2}\right)\end{array}$ & Remarks \\
\hline $\mathbf{1}$ & 45.7 & $30.5 * 57.0$ & 5335 & 7.3 & Bricks \\
\hline
\end{tabular}

Table 3. Splitting tensile strength of the fired brick from Al-Gawhara Palace.

\begin{tabular}{cccccc}
\hline Sp. No. & Weight (g) & $\begin{array}{c}\text { Average Measured } \\
\text { Dimensions } \mathrm{D}^{*} \mathrm{H}(\mathrm{mm})\end{array}$ & $\begin{array}{c}\text { Ultimate } \\
\text { Load (N) }\end{array}$ & $\begin{array}{c}\text { Splitting Tensile } \\
\text { Strength }\left(\mathrm{N} / \mathrm{mm}^{2}\right)\end{array}$ & Remarks \\
\hline $\mathbf{1}$ & 46.2 & $30.2 * 54.6$ & 1035 & 0.40 & Bricks \\
\hline
\end{tabular}

Table 4. Single shear strength of the fired brick from Al-Gawhara Palace.

\begin{tabular}{cccccc}
\hline Sp. No. & Weight $(\mathrm{g})$ & $\begin{array}{c}\text { Average Measured } \\
\text { Dimensions } \mathrm{D}^{*} \mathrm{H}(\mathrm{mm})\end{array}$ & $\begin{array}{c}\text { Ultimate } \\
\text { Load }(\mathrm{N})\end{array}$ & $\begin{array}{c}\text { Single Shear Strength } \\
\left(\mathrm{N} / \mathrm{mm}^{2}\right)\end{array}$ & Remarks \\
\hline $\mathbf{1}$ & 40.1 & $29.2 * 56.9$ & 3110 & 4.6 & Bricks \\
\hline
\end{tabular}

\subsection{Limestone Casing}

The identification of the most probable phases is carried out using PANalytical computer certified program * with the aid of the International Center of Diffraction Database (ICDD) received with the X-ray diffraction equipment.

The limestone sample of the study is mainly composed of calcite granules, most of which are granular (2: $4 \mathrm{UM}$ ) Called microresparate. The sample also 
shows the presence of fossils ( $>4 \mathrm{UM}$ ), which is the size of the calcite calcite (Spavite) or coarse grain. The studied floor consists of calcite, granular flour and some silt (Table 5).

The calcareous limestone of a fossil limestone can be classified as the most fossil content of the sample from fossils of furaminefrera. There is no clear evidence under the polarized microscope that sample damage exists (Figure 19).

Tables 6-8 summarize the mechanical properties of the casing limestone building material (Figure 20 and Figure 21).

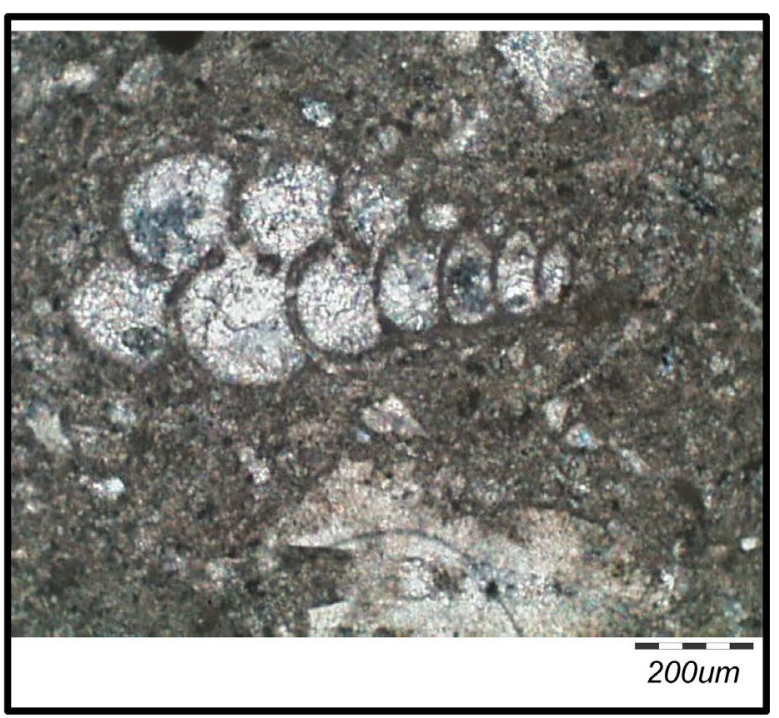

Figure 19. Thin section photomicrograph of the sample submitted by Stone (XPL, 10).
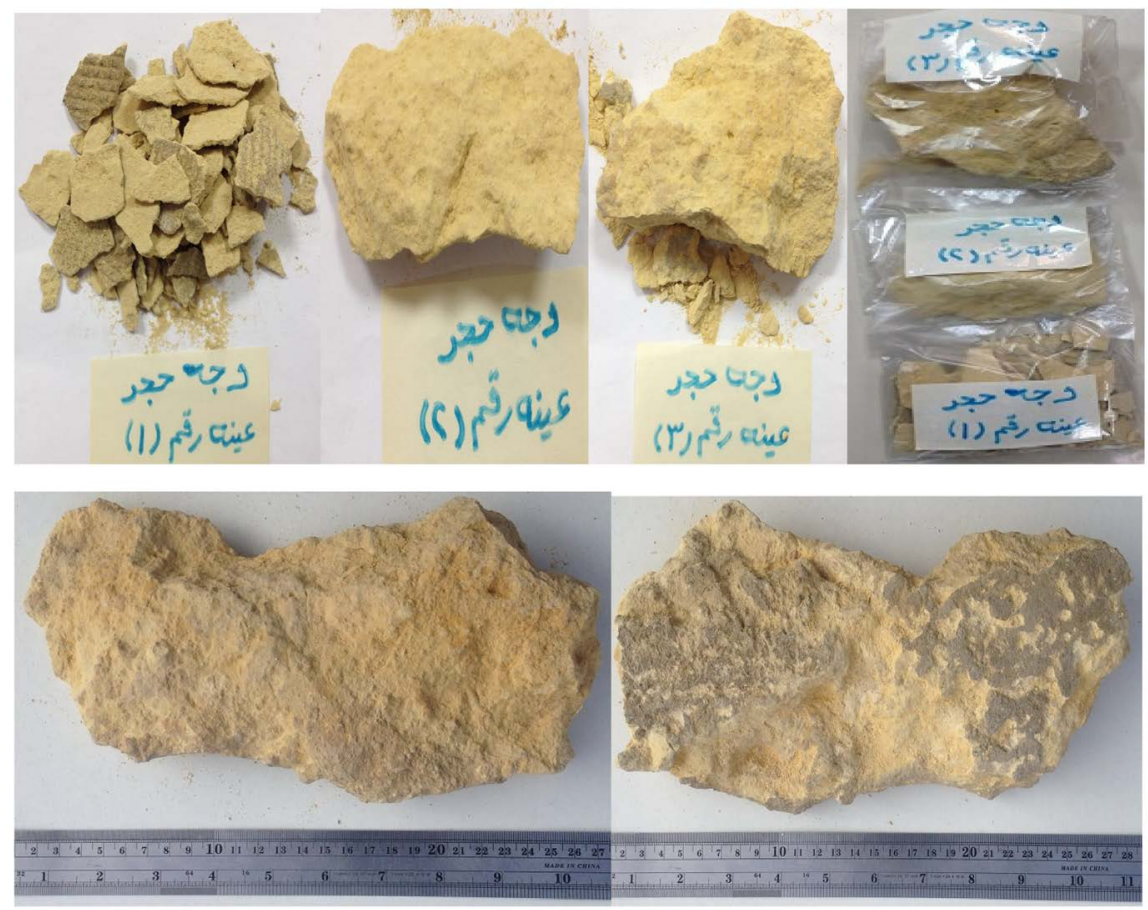

Figure 20. The collected limestone samples. 

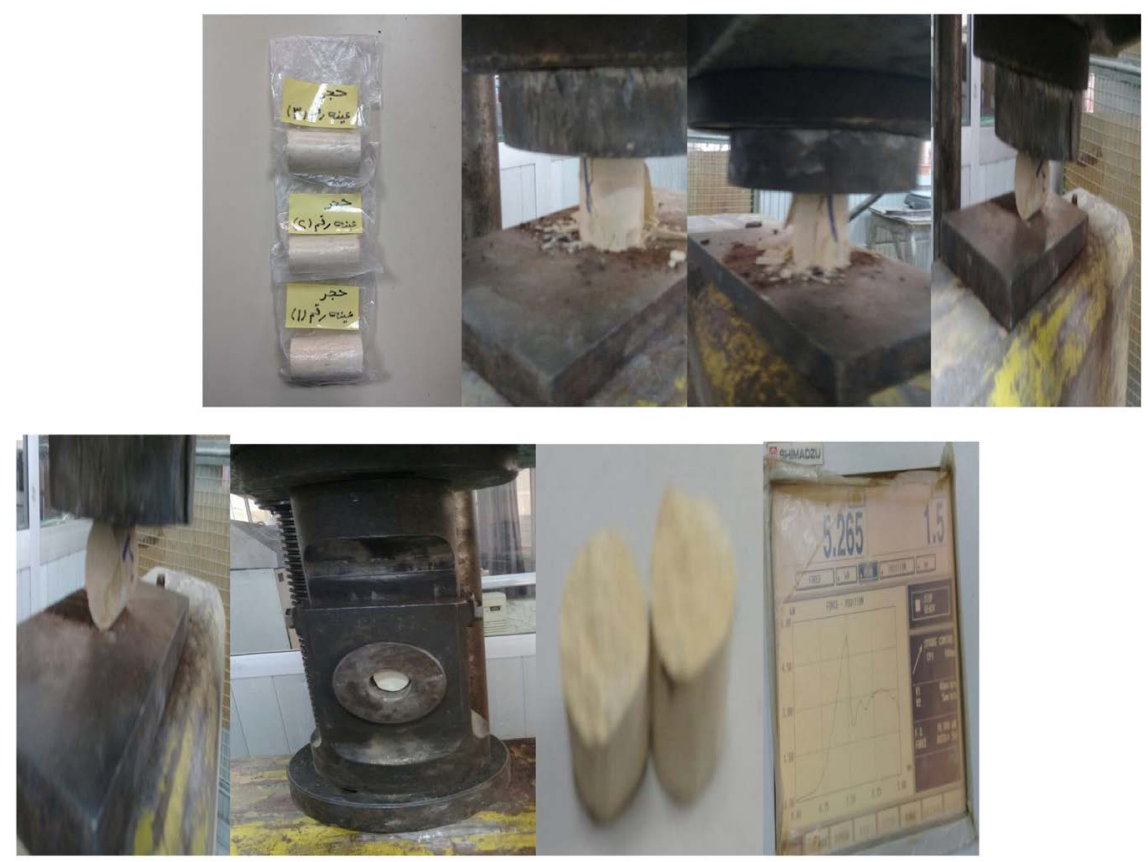

Figure 21. Mechanical testing set-up for the limestone samples.

Table 5. The main compounds of the limestone casing samples.

\begin{tabular}{cc}
\hline Compound Name & Chemical Formula \\
\hline Calcite & $\mathrm{Ca}\left(\mathrm{CO}_{3}\right)$ \\
Quartz & $\mathrm{SiO}_{2}$ \\
\hline
\end{tabular}

Table 6. Splitting tensile strength of the casing limestone from Al-Gawhara Palace.

\begin{tabular}{cccccc}
\hline Sp. No. & Weight $(\mathrm{g})$ & $\begin{array}{c}\text { Average Measured } \\
\text { Dimensions } \mathrm{D}^{*} \mathrm{H}(\mathrm{mm})\end{array}$ & $\begin{array}{c}\text { Ultimate } \\
\text { Load }(\mathrm{N})\end{array}$ & $\begin{array}{c}\text { Splitting Tensile } \\
\text { Strength }\left(\mathrm{N} / \mathrm{mm}^{2}\right)\end{array}$ & Remarks \\
\hline 2 & 164.7 & $40.2{ }^{*} 61.4$ & 3790 & 0.98 & Stone \\
\hline
\end{tabular}

Table 7. Shear strength of the casing limestone from Al-Gawhara Palace.

\begin{tabular}{cccccc}
\hline Sp. No. & Weight $(\mathrm{g})$ & $\begin{array}{c}\text { Average Measured } \\
\text { Dimensions } \mathrm{D}{ }^{*} \mathrm{H}(\mathrm{mm})\end{array}$ & $\begin{array}{c}\text { Ultimate } \\
\text { Load (N) }\end{array}$ & $\begin{array}{c}\text { Single Shear } \\
\text { Strength }\left(\mathrm{N} / \mathrm{mm}^{2}\right)\end{array}$ & Remarks \\
\hline 2 & 167.6 & $40.9 * 59.4$ & 16300 & 12.4 & Stone \\
\hline
\end{tabular}

Table 8. Compressive strength of the casing limestone from Al-Gawhara Palace.

\begin{tabular}{cccccc}
\hline Sp. No. & Weight $(\mathrm{g})$ & $\begin{array}{c}\text { Average Measured } \\
\text { Dimensions } \mathrm{D}^{*} \mathrm{H}(\mathrm{mm})\end{array}$ & $\begin{array}{c}\text { Ultimate } \\
\text { Load }(\mathrm{N})\end{array}$ & $\begin{array}{c}\text { Compressive } \\
\text { Strength }\left(\mathrm{N} / \mathrm{mm}^{2}\right)\end{array}$ & Remarks \\
\hline 2 & 76.8 & $27.3 * 62.3$ & 3020 & 5.2 & Stone \\
\hline
\end{tabular}

\subsection{The Internal Leaf Mortars (Core Mortars between the Two External Leaves)}

The sample consists of the fill mortar of medium quartz granules in addition to some iron oxides shown by the XRD and thin section analysis. There are the 
feldspar crystals in the sample. Calcite is found in the lower left part of the image and is indicated by the arrow (01). Some salts and minerals appear in the sample as raw materials (Table 9, Figure 22 and Figure 23).

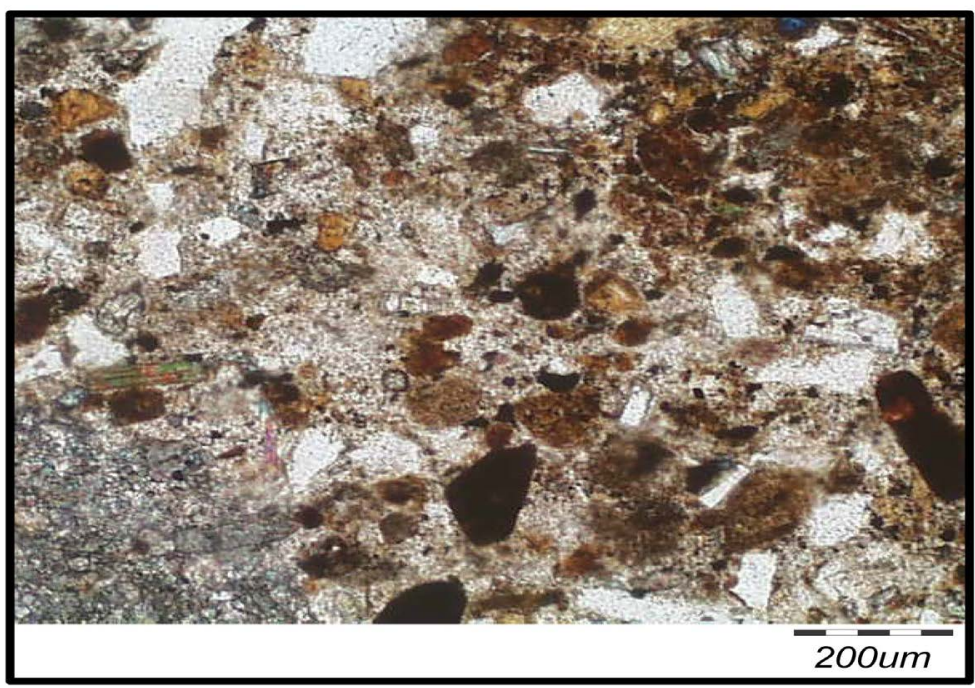

Figure 22. Thin section photomicrograph of the sample submitted by Double wall filler mortar (XPL, 10).
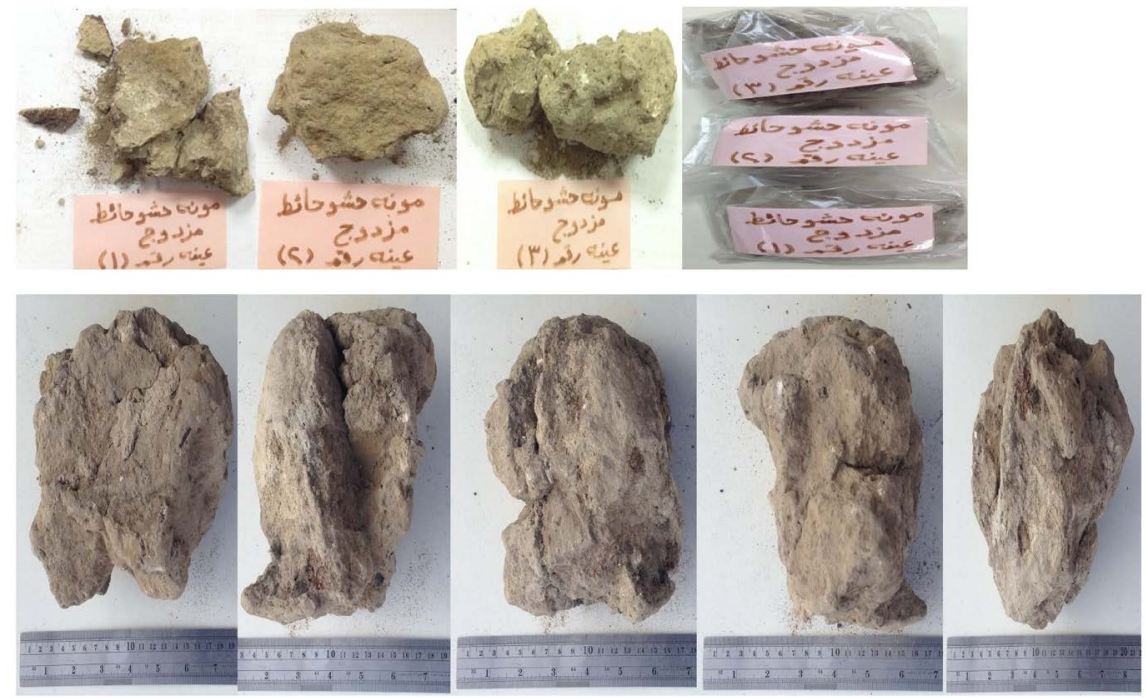

Figure 23. The collected core samples between the two external leaves.

Table 9. The main compounds of the core mortars between the two external leaves.

\begin{tabular}{cc}
\hline Compound Name & Chemical Formula \\
\hline Quartz & $\mathrm{SiO}_{2}$ \\
Calcite & $\mathrm{CaCO}_{3}$ \\
Gypsum & $\mathrm{CaSO}_{4}\left(\mathrm{H}_{2} \mathrm{O}\right)_{2}$ \\
Ilmenite, syn & $\left(\mathrm{Fe}_{0.895} \mathrm{Ti}_{0.105}\right)\left(\mathrm{Fe}_{0.505} \mathrm{Ti}_{0.495}\right) \mathrm{O}_{3}$ \\
Albite & $\left(\mathrm{Na}_{0.98} \mathrm{Ca}_{0.02}\right)\left(\mathrm{Al}_{1.02} \mathrm{Si}_{2.98} \mathrm{O}_{8}\right)$ \\
\hline
\end{tabular}




\subsection{Structural Mortars}

The study of the sample (00) of the structural mortar using the polarized microscope showed that it is composed mainly of quartz crystals (average size). The presence of granular calcite granules (sparite), represented in the excavation of the holes and some calcite, was found to be a component of the soil. Some evaporative metal traces appear in the upper part of the sample. The presence of $\mathrm{CSH}$ as adhesive product has been shown to bind the mortar molecules (Table 10 and Figure 24).

The study of the sample using the polarized microscope revealed that the main component of the mortar of the studied mortar is the large quartz granules (filler) of circular shapes, representing more than $75 \%$ of the studied sample. There are some traces of certain evaporation metals (gypsum). Calcite is also found as granular flour as a solvent between quartz granules. There are some traces of the formation of fine-grained materials on the edges of quartz crystals (Figure 25 and Figure 26).

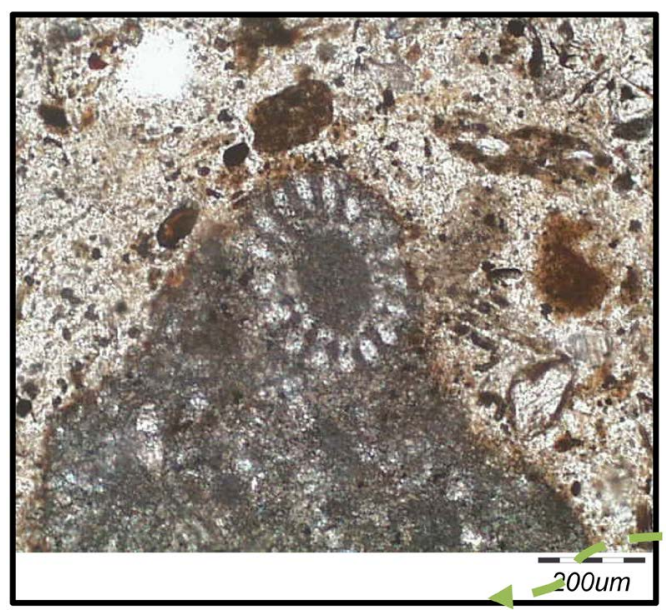

Figure 24. Thin section photomicrograph of the joining mortar samples (XPL, 10).

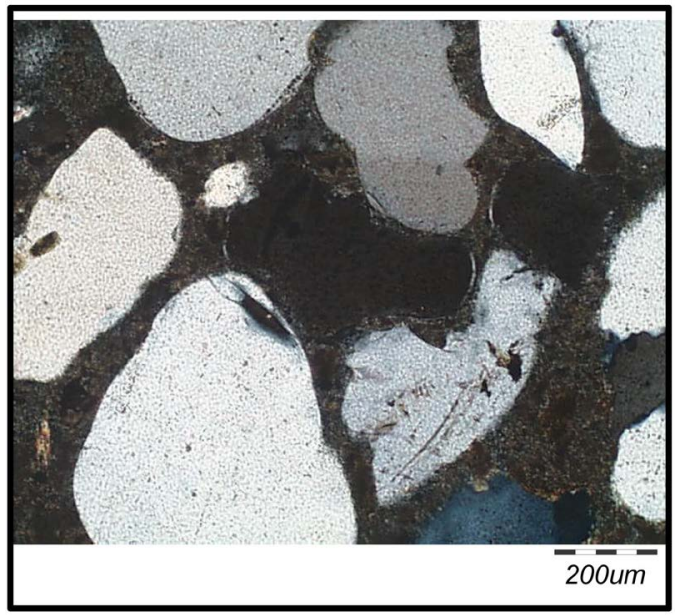

Figure 25. Thin section photomicrograph of the sample submitted by Mortar walls (XPL, $10)$. 

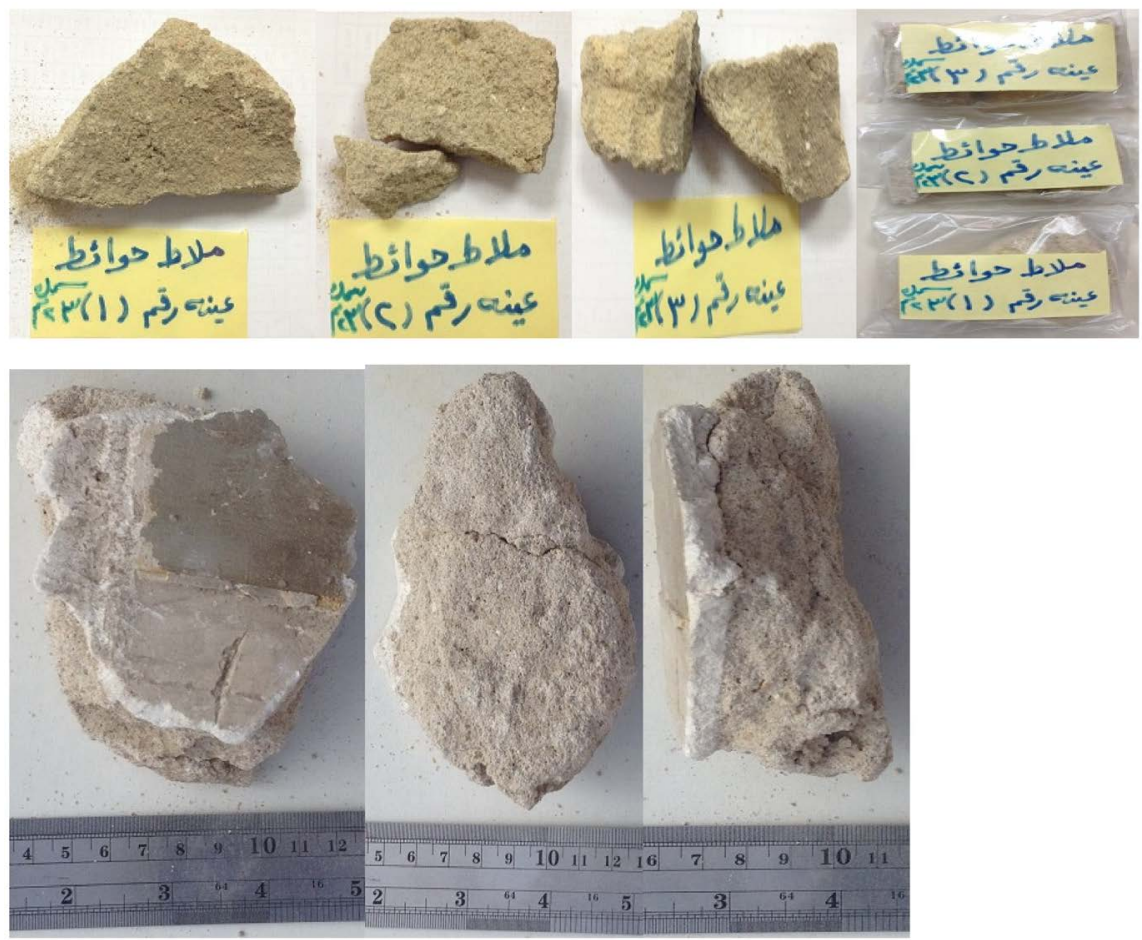

Figure 26. Some collected plaster samples.

Table 10. The compounds of the structural or joining mortars between units.

\begin{tabular}{cc}
\hline Compound Name & Chemical Formula \\
\hline Calcite & $\mathrm{Ca}\left(\mathrm{CO}_{3}\right)$ \\
Quartz & $\mathrm{SiO}_{2}$ \\
$\hat{\mathrm{a}}-\mathrm{Ca}_{2} \mathrm{SiO}_{4}$ & $\mathrm{Ca}_{2} \mathrm{SiO}_{4}$ \\
Calcium Silicate Hydrate & $\mathrm{CaOSiO}_{2} \mathrm{H}_{2} \mathrm{O}$ \\
\hline
\end{tabular}

\subsection{Concrete Plaster}

The study of the polarized microscopic sample of the sample (sample number 6) showed that the sample is composed of concrete Semi-circular and sharp Quatt crystals, in addition to thin, granular calcite granules.

The calcite granules are granulated with nemolite fossils, which are in turn the content of the sample (Table 11). Some of the fine cracks shown in the stock can also be depicted. This may be evidence of some sample damage (Figure 27 and Figure 28).

\section{Structural Analysis of the Building of the Entrance Block and Its Accessories for the Reception Lobby}

The elected programs to simulate the structure were the software SAP2000 (currently, several studies are available in the specialized literature, in which the use of these programs are validated for carry out historical structures analysis). The software allowed us evaluate correctly the linear and non linear behavior of the 


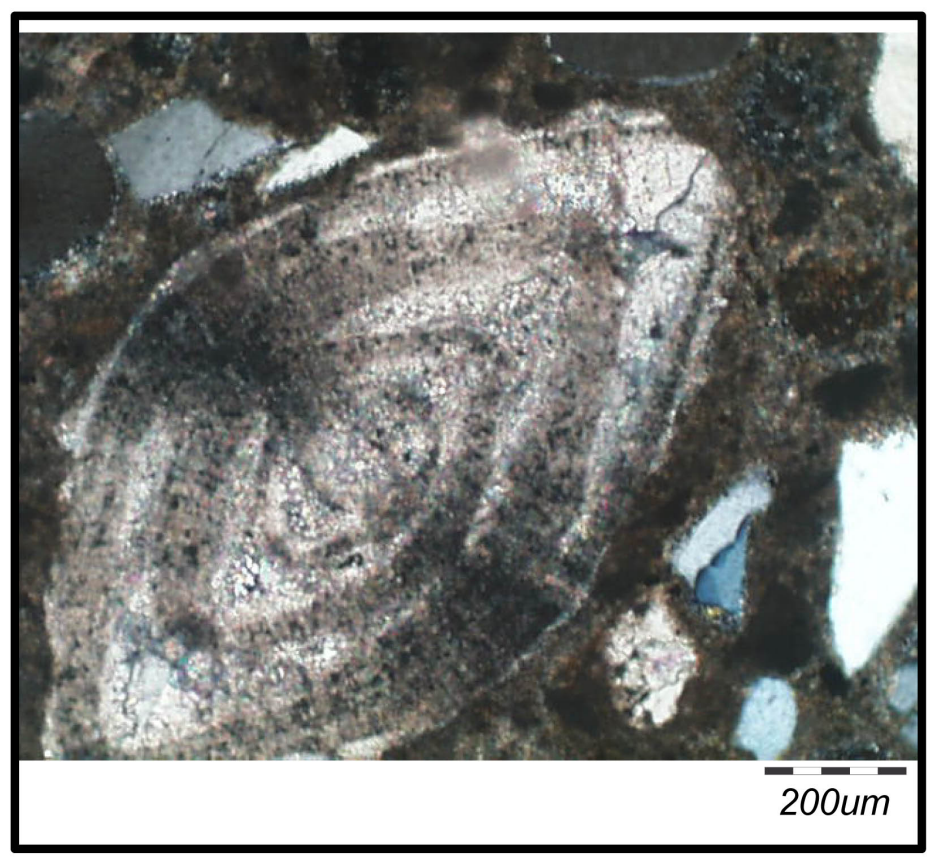

Figure 27. Thin section photomicrograph of the sample submitted by Concrete (XPL, $10)$.

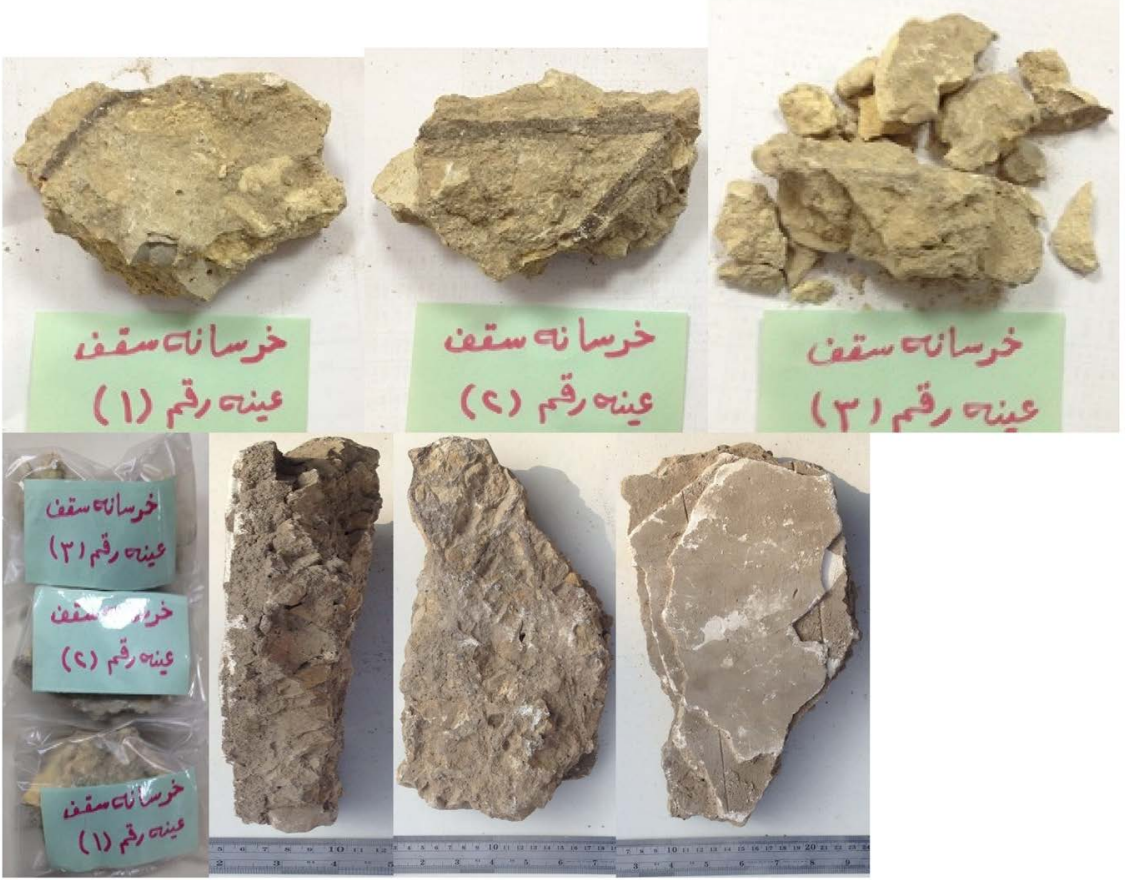

Figure 28. Collected samples from the concrete plaster samples.

Table 11. Chemical composition of the concrete palster.

\begin{tabular}{cc}
\hline Chemical Formula & Compound Name \\
\hline $\mathrm{Ca}\left(\mathrm{CO}_{3}\right)$ & Calcite \\
$\mathrm{SiO}_{2}$ & Quartz \\
\hline
\end{tabular}


masonry. The done analysis with SAP 2000 had the same input features (geometry, materials, boundary conditions, loads and degrees of freedom), in order to perform a verification of the results. The numeric modeling of a real ancient structure (as the Al-Gawhara Palace) is a complex computationally demanding task, nevertheless some general recommendations were followed in order to elaborate a geometric model able to describe adequately the geometry and morphology of the real construction, representing the structural elements in the most simple form for the analysis, then a macro-model of the palace was constructed with shell elements, excluding existing damage and considering constant vertical walls (Figure 29 and Figure 30) [19] [20] [21] [22].

The analyses were performed, and we found that the displacements and stresses obtained with software, were similar having a $\pm 4.0 \%$ of difference (because of these reason is showed the average value). We considered that the

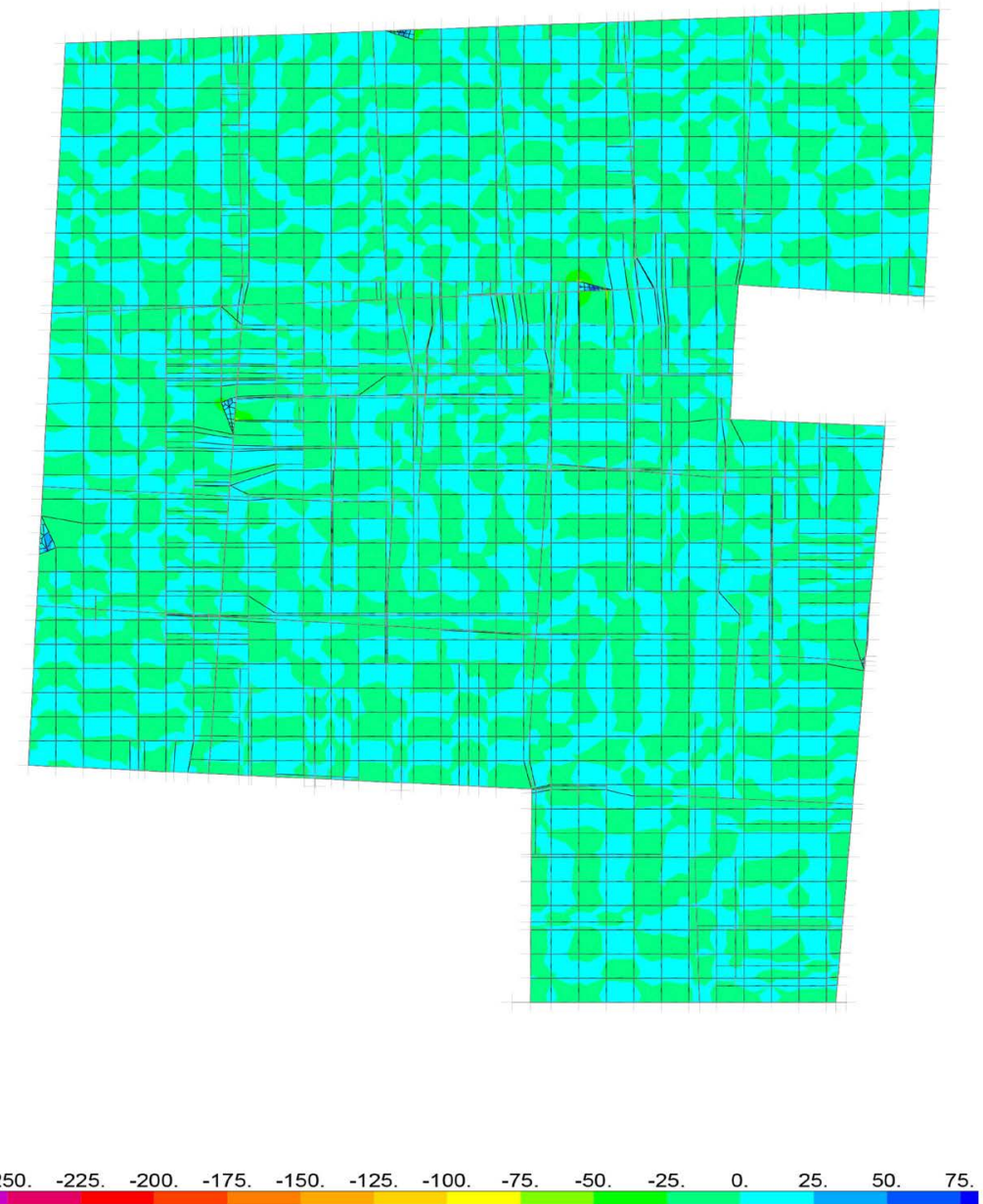

Figure 29. Structural analysis of wooden roof using SAP 2000 Program. 


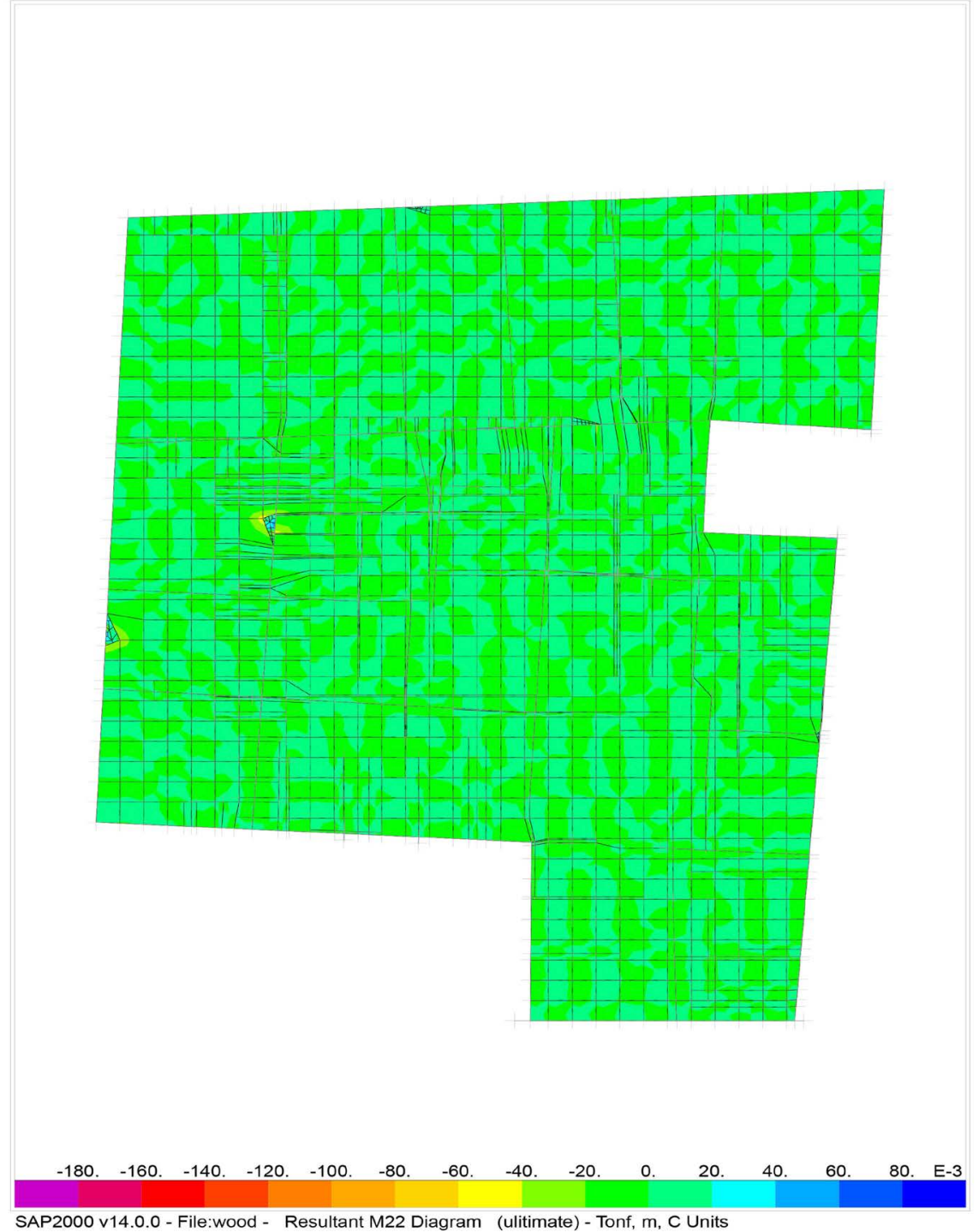

Figure 30. Structural analysis of wooden roof using SAP 2000 Program.

error between the results of the two analyses was despicable and then the numeric analyses are validated. The same results were obtained in the gravitational linear analysis and in the first stage of the non-linear pushover analysis, in which the structure, that also was analyzed affected by self weight, show that the structure did not reach an inelastic behavior at his normal condition. In modal analysis only had a difference in the results while the mode shape is getting higher, this could be explained because SAP2000 solves the system using eigen-vectors. All the maximum compression stresses of the roof did not exceed the maximum allowable, so then we obtained a safety factor of less than 2 in the most unfavorable position, so we can say that in a matter of security, the structure has not the required capacity to support vertical and lateral loads.

In other results, high values of tensional stresses (Figure 31) were observed in the roofing system (as were expected), mainly in the big halls, in which the stress 


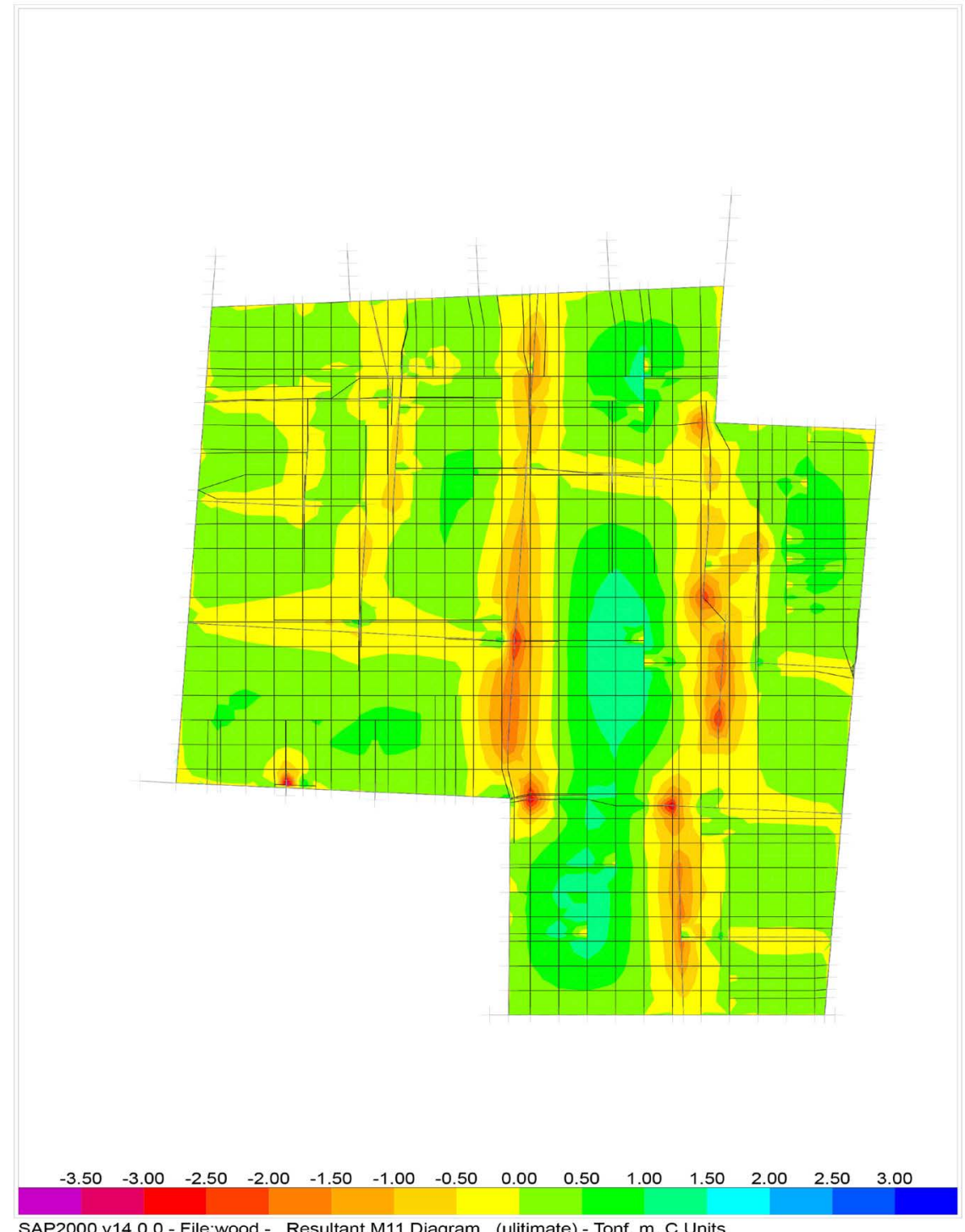

Figure 31. Stress analysis of wooden roof using SAP 2000 Program.

reaches values around the maximum allowable of $3 \mathrm{t} / \mathrm{m}$ (this explain some existing damage), and taking in account that the vaults causes horizontal forces which induce an opening in their bases against the walls in the order of $1.2 \mathrm{~cm}$, this is a warning sign that walls do not have the capacity to support additional loads. Also, the results show that the maximum stress in tension, which exceeds more than twice the stress allowable, is on the rear vault, many damages were inventoried and seen in the area. Based on this there must be some element or factor increasing rigidity or stiffness, because that it support higher tensional stresses.

\section{Proposals for Restoration and Rehabilitation}

The Minor Restoration of the Palace Carried Out in the Same Year 1984 
Most of the repair works that took place were in the movable objects or movable parts that the palace includes as a museum known inside:

1) The damaged drawings, as well as the drawings and inscriptions of the cracked and damaged walls, were completely restored;

2) The drawings and inscriptions on the main entrance and side entrances have been restored;

3) The lobby hall, the Diorama Hall, Al-Keswa Hall and Al-Kushah Hall were restored, as is the original before the fire of 1972;

4) The restoration of hundreds of antiques, such as faucets, wall clocks, antique clocks, lamps, hookahs, dishes and reflections, throne chairs and accessories, weapons, antiques, glassware, rugs and candlesticks was also carried out;

5) Many of the statues were made in real size with the historical clothing of Muhammad Ali and a group of his entourage and soldiers to give it Dayurama representing the Governing Council in the era of Muhammad Ali.

\section{Intervention Retrofitting}

Studying the various cracks and avalanches and classifying them as follows:

1) Crises due to longevity, neglect and maintenance;

2) Crashes and structural deficiency due to the 1992 earthquake and possibly other earthquakes;

3) Cracks and damage caused by the fire that hit Al-Gawhara Palace;

4) Removal of some parts of the Jewel Palace and its accessories in the past due to the foot of origin;

5) Study and characterization of various structural methods to treat cracks and cracks in the palace and its extensions.

\section{Proposals for Development and Modernization}

- Re-Palace Jewel and accessories to what was above;

- Rafah is part of the palace and its annexes according to the current situation;

- Identification of collapsed areas destroyed by fire;

- Rebuilding, deleting, and treating collapsed parts with the old look;

- Recycle all damaged and damaged woodwork in old appearance;

- Renovation of all the Kranish and the walls and works of art while preserving the ancient archaeological appearance;

- Restoration of all floors with the same materials used in the past as wooden floors and marble;

- Re-paint and paint all new walls and ceilings with old appearance;

- Furniture and collectibles in the Jewel Palace and accessories.

All furniture and artifacts are currently limited to minors and classified into:

Furniture and art objects for minors and used in the past.

Furniture pieces and art objects were entered and placed in the palace without being exclusive to the palace originally.

- Restoration and restoration of all furniture, preserving the style and historical period it represents;

- Repairing and remedying any damage to art objects; 
- The work of the horizontal horizon of the palace and accessories and the distribution of furniture and artifacts in the spaces allocated. According to the historical periods and the events witnessed by the palace. However, it determines the path taken by the visitor to see all the buildings of the palace and its annexes;

- Studying the technical elements and modern systems of Al-Jawhara Palace and its annexes;

- The appropriate way to illuminate the palace from the outside and inside and show the architectural and artistic instincts;

- Secure all external openings such as entrances and windows and anti-theft alarm systems;

- Internal security of the palace and its annexes and all the display areas by means of anti-theft alarms, especially paintings and valuable artistic possessions, and the establishment of certain secret fingerprints on all pieces and artifacts;

- Provide all parts of minors by means of automatic fire alarm and means of fire resistance with the description of automatic fire extinguishing means according to each area and the quality of their art holdings;

- Study the internal lighting of each area and characterize it according to the quality of the furniture and technical holdings to show the beauty, value and art of each piece, taking into account the other influences in the vacuum or space in which the presentation. And the effect of natural lighting, especially that some areas have many windows;

- Study the installation of central vacuum system (Central Vacuum System) cleaning with vacuum cleaner to remove dust from furniture and artifacts, curtains and walls ... etc.;

- Study the entrances and exits of emergency according to the sound technical assets and the installation of electronic devices at the entrances and exits to be calculated to calculate the number of visitors and determine.

\section{Adaptive Reuse of the Palace}

Al-Gawhara Place has been reused many times throughout its history. The current discourse of diverse trends in preservation together with awareness for sustainable environments has led to a surge in adaptive reuse projects. The combination of new and old architecture ensures the retaining of authentic character while providing an appropriate new use and revitalizing the structure. Learning from precedents is one of the most important knowledge bases for architects. It has many layers of knowledge referring to the old building and its original use, the transformed building and its new use, and the transformation itself. The objective of this work is to propose a theoretical and practical background for a systematic process to support adaptive reuse of the palace as historic museum. A procedure for the analysis has been developed to fit the specific nature of this architecture data. Figure 32 refers to the adaptive reuse proposal of the palace. 


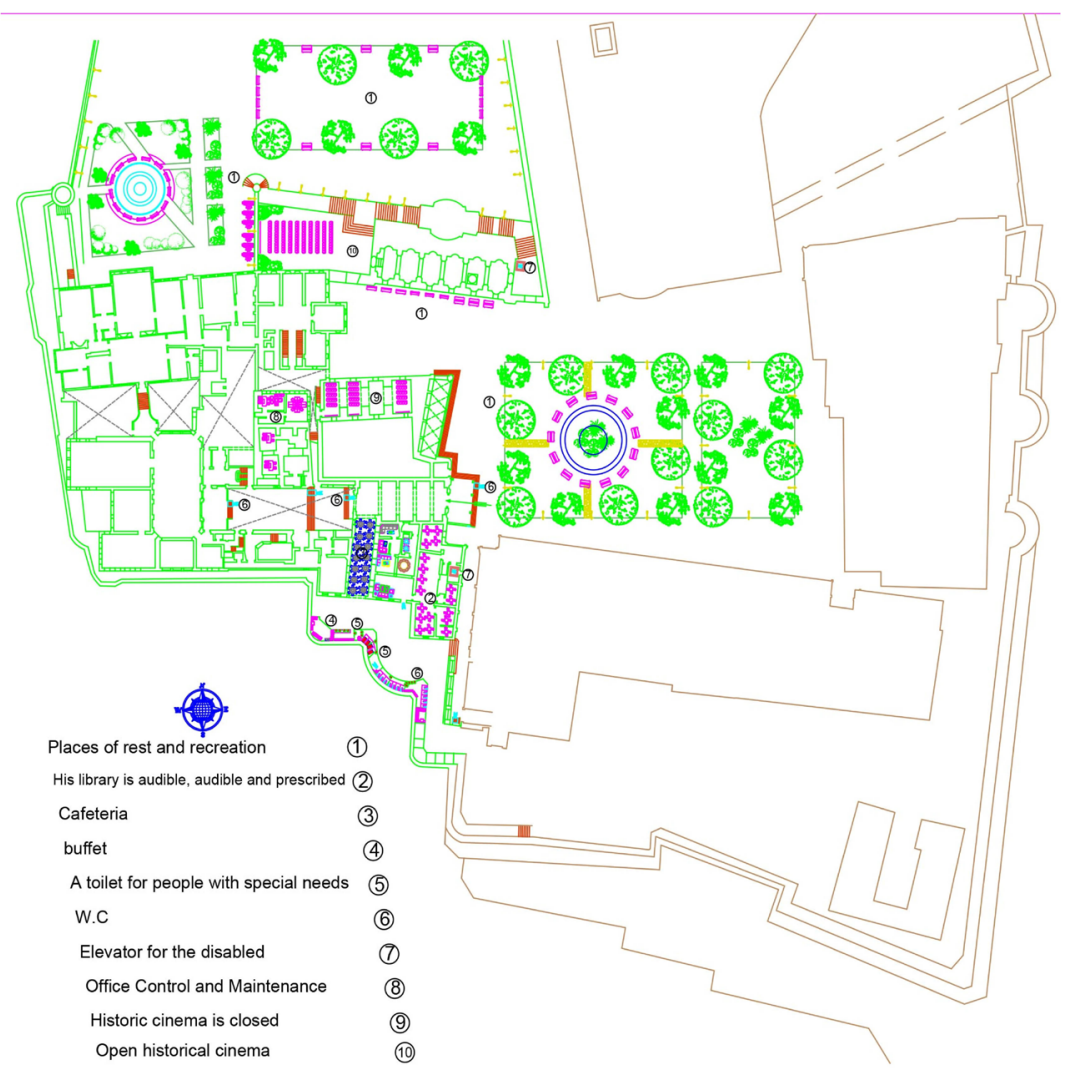

Figure 32. The proposal for the reuse of Al-Gawhara Palace.

\section{Conclusion}

In this paper was presented an adapted methodology that was followed with the aim of performing a structural analysis and adaptive rehabilitation of the AlGawhara Palace in Cairo, Egypt. According to the results obtained, it can be concluded that the palace presents structural unsafety conditions for their normal use. The unique areas which present higher stresses than the expected are the roofs and walls; there is a match of them with the cataloged damage. According to the modal analysis results and those obtained from previous studies of S.H.M., it is partially concluded that the consideration about the use of the Young's modulus to perform a modal updating is possible numerically. Recommendations specify that sedimentary limestone materials for typical ancient masonry structures could have strength values between 10 and $100 \mathrm{~N} / \mathrm{mm}^{2}$, but considering 5.4 times the value of $\mathrm{fk}$ for a future analysis couldn't be a suitable option to perform it because fk is also in function of the mortar, and even modern mortars cannot achieve strength over $10 \mathrm{~N} / \mathrm{mm}^{2}$. Such higher value of fk obtained theoretically indicates that a factor could exist, which causes high stiffness of the overall structure; research should be done to understand this factor.

\section{Conflicts of Interest}

The authors declare no conflicts of interest regarding the publication of this paper. 


\section{References}

[1] Wahab, H.A. (2010) Library of Architecture, Volume III, The Hundredth Feast of the Mosque of Muhammad Ali Pasha Al-Kabeer. Cairo, 28.

[2] Zaky, A.R. (1987) Cairo Encyclopedia in the Thousand Years. Cairo, 205.

[3] Al-Jabarti, A.R. (1988) The Wonders of Archeology in the Translations and News, the Investigation of Abdulrahim Abdel Rahman. Cairo, C4, 28.

[4] Al-Amayim, M.A. (2008) An Article Describing the Fortress of Egypt in the Late 19th Century through the Map of Colonel Green. 115.

[5] Hamdy, M. (2010) The Urban and Architectural Development of the Southwestern Square of the Citadel of Salah Al-Din Ayyubi in Cairo Since the Ayyubid Era Until the End of the Ottoman Era.

[6] De Vogani (2004) Cairo and Its Suburbs. Translated by Medhat Aida Fahmy, Cairo, Vol. 1, 182-183.

[7] Rabbat, N.O. (2009) The Citadel of Cairo.

[8] Kafafy, H. and Ali, M. (1992) Vision of the Incident of the Castle. The Egyptian General Book Organization, Cairo, 70.

[9] Citadel of Salah al-Din, Inspection of the Castle. 89.

[10] Azab, K. (2006) Aswar and Qal'at Salah Eddin. Zahraa Al Sharq Library, Cairo, 23.

[11] Hawass, S.Z. (2001) Cairo Khedive "Monitoring and Documentation Amara and Amran Downtown Area. Cairo.

[12] Sidkrim (1941) Muhammad Ali's House. Al-Amara Magazine, No. 403, 14, 16.

[13] Zaky, A.R. (1960) Citadel of Salah Al-Din and Contemporary Islamic Castles. Library Nahdet Egypt and Printing, 74.

[14] Okasha, A. (2008) Islamic Architecture in Egypt. Giza, 73.

[15] Marzouk, A.A. (1970) Islamic Decorative Arts. 76.

[16] Mubarak, A.P. (2010) The New Conciliatory Plans for Egypt Cairo for Its Old and Famous Cities and Countries. The Amiri Printing Press, Cairo, 83.

[17] Hemeda, S. and El-banna, S. (2014) Structural Deficiency and Intervention Retrofitting Measures of Rubble Flled Masonry Walls in Islamic Historical Buildings in Cairo. Mediterranean Archaeology and Archaeometry, 14, 235-246.

[18] Hemeda, S., Akarish, A.I.M. and El-Nagga, A.A. (2018) Engineering Investigations and Durability Problems of the Construction Materials of the Roman Babylon of Egypt. Open Journal of Geology, 8, 404-436.

[19] Hemeda, S. and Pitilakis, K. (2017) Geophysical Investigations at Cairo's Oldest, the Church of Abu Serga (St. Sergius), Cairo, Egypt. Research in Nondestructive Evaluation, 28, 123-149.

[20] Hemeda, S. (2014) Seismic Hazard Analysis for Preservation of Architectural Heritage: The Case of the Cairo's Oldest Abu Serga Church. International Journal of Civil Engineering, 3, 2.

[21] Hemeda, S. (2016) Non-Linear Static Analysis and Seismic Performance of Modern Architectural Heritage in Egypt. Mediterranean Archaeology and Archaeometry, 16, $1-15$.

[22] Hemeda, S. (2019) 3D Finite Element Coupled Analysis Model for Geotechnical and Complex Structural Problems of Historic Masonry Structures: Conservation of Abu Serga Church, Cairo, Egypt. Heritage Science, 7, 6. 